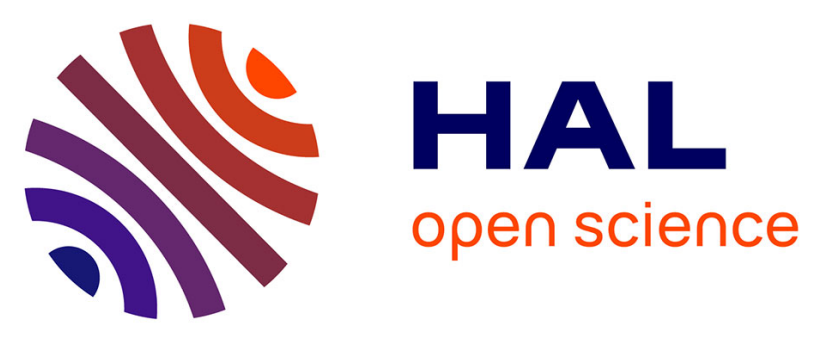

\title{
Incremental Emplacement of the Late Jurassic Midcrustal, Lopolith-Like Qitianling Pluton, South China, Revealed by AMS and Bouguer Gravity Data
}

Hongsheng Liu, Guillaume Martelet, Bo Wang, Saskia Erdmann, Yan Chen, Michel Faure, Fangfang Huang, Bruno Scaillet, Nicole Le Breton, Liangshu Shu, et al.

\section{To cite this version:}

Hongsheng Liu, Guillaume Martelet, Bo Wang, Saskia Erdmann, Yan Chen, et al.. Incremental Emplacement of the Late Jurassic Midcrustal, Lopolith-Like Qitianling Pluton, South China, Revealed by AMS and Bouguer Gravity Data. Journal of Geophysical Research: Solid Earth, 2018, 123, pp.9249-9268. 10.1029/2018jb015761 . insu-01914809

\section{HAL Id: insu-01914809 \\ https://hal-insu.archives-ouvertes.fr/insu-01914809}

Submitted on 7 Nov 2018

HAL is a multi-disciplinary open access archive for the deposit and dissemination of scientific research documents, whether they are published or not. The documents may come from teaching and research institutions in France or abroad, or from public or private research centers.
L'archive ouverte pluridisciplinaire HAL, est destinée au dépôt et à la diffusion de documents scientifiques de niveau recherche, publiés ou non, émanant des établissements d'enseignement et de recherche français ou étrangers, des laboratoires publics ou privés. 


\section{Journal of Geophysical Research: Solid Earth}

\section{RESEARCH ARTICLE \\ 10.1029/2018JB015761 \\ Key Points: \\ - The Jurassic Qitianling pluton was \\ Incremental Emplacement of the Late Jurassic Midcrustal, Lopolith-Like Qitianling Pluton, South China, Revealed by AMS and Bouguer Gravity Data} emplaced as a lopolith- to sill-like body at the upper part of the middle crust (at $\sim 10-15 \mathrm{~km}$ ) during a period of tectonic quiescence

- The pluton was constructed by downward accretion of multiple magma pulses ascent along pipe-like channels

- Anisotropy of Magnetic Susceptibility is an efficient tool for identifying possible contacts between incrementally emplaced magma pulses

Supporting Information:

- Supporting Information S1

Correspondence to:

B. Wang,

bwang@nju.edu.cn;

burh_cw@yahoo.com

Citation:

Liu, H., Martelet, G., Wang, B., Erdmann, S., Chen, Y., Faure, M., et al. (2018). Incremental emplacement of the Late Jurassic midcrustal, lopolith-like Qitianling pluton, South China, revealed by AMS and Bouguer gravity data. Journal of Geophysical Research: Solid Earth, 123. https://doi.org/10.1029/ 2018JB015761

Received 20 MAR 2018 Accepted 30 SEP 2018 Accepted article online 9 OCT 2018

\author{
Hongsheng Liu' ${ }^{1,2,3,4}$, Guillaume Martelet ${ }^{2,3}$, Bo Wang' ${ }^{1}$, Saskia Erdmann ${ }^{3}$ (D), Yan Chen ${ }^{3}$, \\ Michel Faure $^{3}$ iD, Fangfang Huang ${ }^{1,3}$, Bruno Scaillet $^{3}$ (D) Nicole le-Breton ${ }^{3}$, Liangshu Shu ${ }^{1}$ (D), \\ Rucheng Wang ${ }^{1}$, and Jinchu Zhu' \\ ${ }^{1}$ State Key Laboratory for Mineral Deposits Research, School of Earth Sciences and Engineering, Nanjing University, Nanjing,
China, ${ }^{2}$ Université d'Orléans, ISTO, CNRS/INSU, UMR 7327, Orléans, France, ${ }^{3}$ BRGM, UMR 7327, BP 36009, Orléans, France,
${ }^{4}$ Computational Geosciences Research Centre, Central South University, Changsha, China
}

Abstract Modes of magma emplacement may provide key information on geodynamic-tectonic settings of magmatism, when the threshold of magma volume and duration of emplacement process is crossed, brittle/ductile crustal deformation behavior, and volumes and rates of magma transfer in the crust. The majority of upper-crustal granitic intrusions are incrementally emplaced as laccoliths or sills, while midcrustal or deeper-level granitic intrusions appear to be predominantly emplaced as sills or lopoliths, but relatively few examples have been studied. We present a case study on the Jurassic Qitianling pluton from South China, which was constructed in the upper part of the middle crust (at a depth of $\sim 10-15 \mathrm{~km}$ ). To characterize its emplacement mechanism and evolution, we have combined field and microscopic observations, Anisotropy of Magnetic Susceptibility measurements and Bouguer gravity anomaly modeling. The main findings are (1) the generally undeformed granite-country rock contacts with a narrow thermal aureole, (2) irregularly wavy and gradational contacts between the main granite facies, (3) dominant subhorizontal magnetic fabrics in the granites with a scattered magnetic foliation, (4) rare occurrence of dykes, and (5) a subcircular surface and lopolith-like pluton geometry. Accordingly, we suggest that the Qitianling pluton forms an $\sim 25-\mathrm{km}$ wide and $\sim 5-\mathrm{km}$ thick lopolith that was incrementally emplaced during a period of tectonic quiescence, most likely by under-accretion of multiple magma sheets deflected from magma pulses that ascended through pipe-like channels. The mineralogical and compositional variation of the pluton may be the result of in situ fractionation, fractionation at deeper crustal level, or variation in source-derived melt compositions.

\section{Introduction}

Magmatic rocks form a large proportion of the continental crust. Constraining the production, segregation, ascent, and emplacement or eruption of magmas is thus of fundamental importance for a comprehensive understanding of the evolution of the continental crust. Characterizing the emplacement of intrusions and intrusion-country rock relations may provide key constraints on geodynamic or tectonic setting, brittle-toductile crustal behavior, and volumes and rates of magma transfer within the crust or between mantle and crust (e.g., Byerly et al., 2016; de Saint Blanquat et al., 2011; Paterson, 2009). On the basis of previous studies of the geometry, petrology, and duration of the construction of intrusions, combined with researches on the fabrics and physical properties of intrusive bodies and country rocks, and spatially and/or temporally related regional tectonics, several end-member models for crustal magma ascent and emplacement have been proposed: (1) ascent and emplacement by dyking (e.g., Gudmundsson, 2011; Hutton, 1992; Ni et al., 2016; Scaillet et al., 1996), (2) magma ascent and emplacement in diapirs (e.g., Bateman, 1984; He et al., 2009; Potro et al., 2013), and (3) ascent through dyking or in diapirs yet emplacement in tabular bodies, that is, laccoliths, sills, or lopoliths (e.g., Morgan et al., 1998; O'Driscoll et al., 2006; Scaillet et al., 1995; Schofield et al., 2012; Stevenson et al., 2007). Magma ascent and transport may take place syn-tectonically (e.g., Allibon et al., 2011; de Saint Blanquat \& Tikoff, 1997; Wei et al., 2016) or during periods of tectonic quiescence (e.g., de Saint-Blanquat et al., 2006). Most studies have been carried out on plutons that were emplaced into the upper continental crust (i.e., at depths of $<10$ km; e.g., Cruden, 1998; Petford et al., 2000, and references therein), while emplacement of plutons in midcrustal and deep-crustal levels has been investigated in fewer studies (Clemens et al., 2017; de Saint-Blanquat et al., 2001; Dumond et al., 2005). 


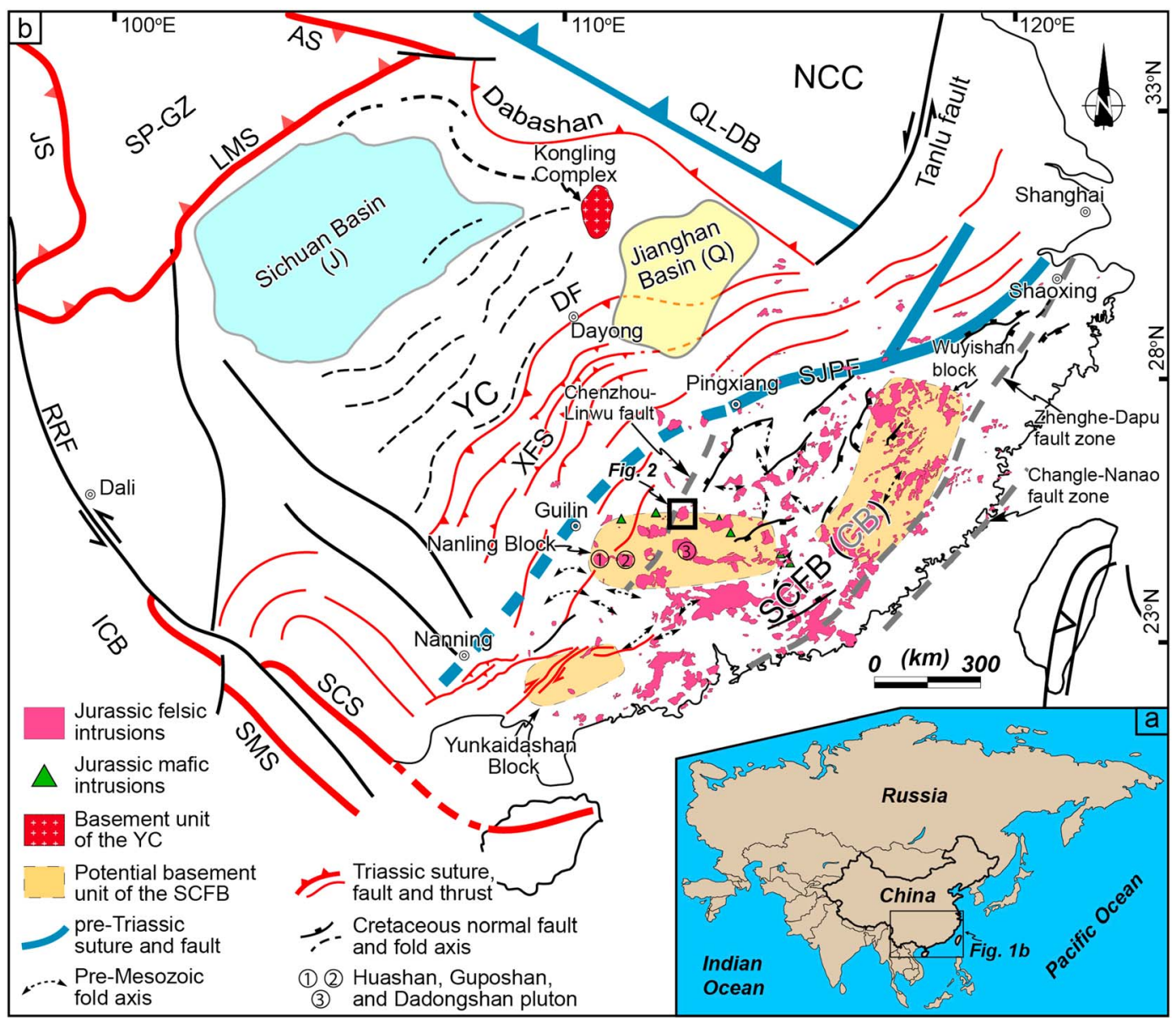

Figure 1. (a) Map of the Asian continent; (b) tectonic framework of the South China Block and exposure of Jurassic felsic and mafic intrusions. The inset in (b) indicates the location of the Qitianling pluton. Abbreviations: NCC: North China Craton, SP-GZ: Songpan-Ganzi Block, ICB: Indo-China Block, YC: Yangtze Craton, CB: Cathaysia Block, SCFB: South China Fold Belt, QL-DB: Qinling-Dabie Orogen, LMS: Longmenshan Suture, JS: Jinshajiang Suture, SJPF: Shaoxing-Jiangshan-Pingxiang Fault, AS: Animaqin Suture, RRF: Red River Fault, SCS: Songchai Suture, SMS: Songma Suture, XFS: Xuefengshan Belt, DF: Dayong Fault. The Sichuan Basin is covered by thick Jurassic (J) sediments. The Jianghan Basin is a Quaternary (Q) sedimentary basin.

The South China Block (SCB), which hosts the Qitianling pluton that we have studied, comprises abundant Mesozoic granitic plutons that crop out over $>127,000 \mathrm{~km}^{2}$ (Zhou et al., 2006). Jurassic plutons make up $\sim 30-40 \%$ of the exposure of the Mesozoic granites (Figure 1b). Numerous geochronological and geochemical studies have been carried out on the Jurassic plutons (Chen \& Jahn, 1998; Zhou et al., 2006, and references therein), but no quantitative data are available to constrain their internal fabric and granite-country rock intrusive relations (Zhu et al., 2009). The Qitianling pluton, which formed at 146-163 Ma (SHRIMP and LA-ICP-MS zircon U-Pb ages by Zhu et al., 2009) in the southeastern part of the SCB, is a well-known example of a midcrustal intrusion, which crystallized at $\geq 3.6 \pm 0.9 \mathrm{kbar}$ and thus at a depth of $\geq 9-14 \mathrm{~km}$ (Zhao et al., 2005).

In order to put constraints on the emplacement mechanism of midcrustal intrusions and to provide insights into the crustal evolution of the SCB, the Qitianling intrusion was targeted because (1) its internal magmatic textures and sharp granite-country rock contact are representative for most of the Jurassic granites in SE China (Zhou et al., 2006), (2) its geochemical variation and intrusion ages are well documented, (3) its emplacement depth is constrained, (4) Bouguer gravity anomaly data are available for restoring the 3-D geometry of the pluton, and (5) it has larger and mostly unaltered outcrops (in quarries) compared to other Jurassic intrusions of the SCB. In this paper, we present detailed field and microscopic observations, Anisotropy of Magnetic Susceptibility (AMS) measurements, and gravity modeling to comprehensively characterize the emplacement mechanism and the evolution of the Qitianling pluton. 


\section{Geological Setting}

\subsection{The South China Block}

The SCB is a composite continental plate that was formed by the amalgamation of the Yangtze Craton in its northwestern part and the Cathaysia Block in its southeastern part along the NE-SW-striking ShaoxingJiangshan-Pingxiang Fault (SJPF in Figure 1b) at 850 Ma (e.g., Faure et al., 2016; Li et al., 2008). According to previous studies, the nature and basement compositions of the Yangtze Craton and the Cathaysia Block are significantly different (Figure 1; Chen \& Jahn, 1998; Fletcher et al., 2004). The Yangtze Craton is a rigid and stable craton consisting of Precambrian basement including Archean TTGs ( 3.3-Ga Kongling Complex in Figure 1b; Gao et al., 2011). Geophysical data have revealed a homogeneous and $45-\mathrm{km}$-thick crust (Deng et al., 2014). The Cathaysia Block also comprises Precambrian basement, but it consists of at least three microblocks, namely, the Wuyishan, Nanling, and Yunkaidashan subunits comprising Paleo- to Mesoproterozoic ( 1.1-2.5 Ga) metasedimentary and intrusive rocks (Wan et al., 2007; Yu et al., 2009, 2010). Geophysical investigations have also revealed heterogeneous density layers, indicating a complex crustal structure (Deng et al., 2014; Fletcher et al., 2004).

The SCB as a whole has experienced pervasive and polyphase tectono-magmatic events after its agglomeration at 850 Ma: (1) Neoproterozoic rifting (Nanhua rifting; Shu, Faure, et al., 2011; Wang \& Li, 2003; Zheng et al., 2008), (2) an Early Paleozoic intracontinental orogeny (Charvet et al., 2010; Faure et al., 2009; Wang et al., 2010; Zhang et al., 2013), (3) Middle Triassic continental collision with the Indochina block to the south/southwest and with the North China block to the north (Faure et al., 2008, 2014; Gilder et al., 1999; Lin et al., 2005), and (4) Mid-Triassic intracontinental deformation along the NNE-SSW-striking Xuefengshan belt in the central part of the SCB (Figure 1b; Chu et al., 2012; Wang et al., 2007; Yan et al., 2011). Intense regional deformation has thus reworked not only the borders of the SCB in the northern (Qinling-DabieDabaShan), western (Longmenshan), and southwestern (Yunkaidashan-Ailaoshan) parts but also the central part of the SCB (red solid lines in Figure 1b). The southeastern central part of the SCB, the highly deformed ancient Cathaysia Block, was most extensively involved in regional deformation events possibly due to its low basement rigidity, and this region has thus been referred to as the South China Fold Belt (SCFB in Figure 1) (Huang, 1945).

Jurassic strata, however, which mostly consist of sandstone in the study area, show only large-scale open folds, showing no evidence for penetrative deformation (i.e., high-temperature foliations or lineations; Shu et al., 2009) following the Triassic. Evidence for ductile or syn-emplacement deformation is equally devoid in Jurassic plutons in the SCB, including the Qitianling pluton and the spatially associated HuashanGuposhan and Dadongshan plutons (Figure 1b; Feng et al., 2012; Shu, Wang, et al., 2011). The Jurassic plutons in SE China moreover show a random distribution (Figure 1); that is, they are in no way spatially grouped (e.g., in linear intrusive belts).

\subsection{The Qitianling Pluton}

The granitic Qitianling pluton has a subcircular surface exposure with an area of ca. $530 \mathrm{~km}^{2}$ (Figures 1 and 2a). Zircon U-Pb ages of the granites range from ca. 146 to $163 \mathrm{Ma}$ (Figure 2b; Zhu et al., 2009). The pluton has intruded Carboniferous, Permian, and Triassic strata comprising limestone, mudstone, and sandstone (Figure 2a). Triassic and pre-Triassic strata are folded with NE-SW-striking fold axes (BGMRHN (Bureau of Geology and Mineral Resources of Hunan Province), 1988), forming part of the Xuefengshan fold-and-thrust belt. Mesozoic sediments are rare in the study area (Figure 2a). The Qitianling pluton comprises three main granitic facies: (1) facies I, which consists of amphibole- and biotite-bearing, coarse- to medium-grained granite with locally abundant mafic enclaves and K-feldspar megacrysts (Figures 2a, 4a, and 4d); (2) facies II, which is composed of medium- to fine-grained, biotite \pm amphibole-bearing granite, and rare centimeter-sized mafic enclaves (Figures 2a and 4b); and (3) facies III, which is a medium- to fine-grained biotite granite that lacks mafic enclaves (Figures $2 \mathrm{a}$ and $4 \mathrm{c}$ ). The three facies are metaluminous to weakly peraluminous with $\mathrm{A} / \mathrm{CNK}$ values ranging between 0.91 and 1.1, and $\mathrm{SiO}_{2}$ contents ranging between $\sim 65 \%$ and $76 \%$ (Bai et al., 2005; Deng et al., 2005; Zhao et al., 2005). The composition of calcic amphibole in the facies I granites indicates a crystallization pressure of $\sim 3.6 \pm 0.9$ kbar (Zhao et al., 2005) calculated using Al-inhornblende barometry. 

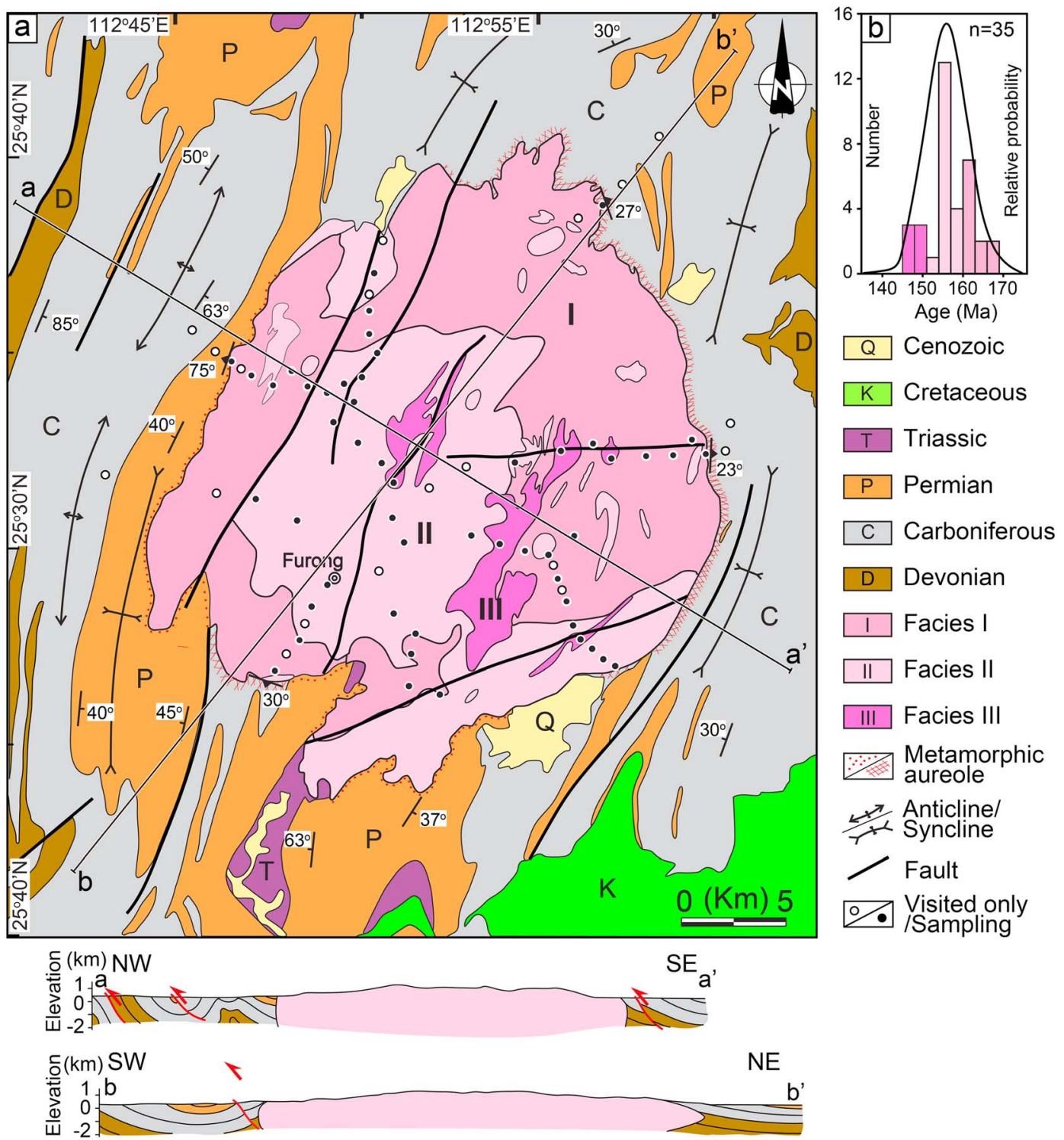

Figure 2. (a) Geological map of the Qitianling pluton and its country rocks with two geological profiles, that is, aa' and bb' (modified after Zhu et al., 2009); (b) zircon U-Pb ages of the Qitianling pluton compiled from Zhu et al. (2009). The filled black and gray circles mark outcrops that were sampled and observed only, respectively.

\section{Field Observations and Sampling}

Our field investigations were conducted in 72 outcrops in the Qitianling pluton and its country rocks as well (Figure 2). Previous mapping (BGMRHN, 1988; Zhu et al., 2009) and our observations show that the facies II granite forms the topographically most elevated parts $(\sim 1,356 \mathrm{~m})$ of the intrusion, while facies I ( 340-980 $\mathrm{m}$ ) and facies III granites ( 550 to 1,130 m) occur at variable elevations (Figure 2a and Table S1 in the supporting information).

The contact between the granites and the country rocks is irregular at the kilometer-scale with short granite lobes extending in NNE-SSW direction (Figure 2). Country-rock xenoliths have not been observed in the field. The northern, southern, and eastern margins of the pluton have gently outward dipping $\left(\sim 20-30^{\circ}\right.$; Figures 2 , $3 a, 3 b$, and $3 c$ ) contacts with the country rocks. In contrast, the exposed granite-country rock contact at the western margin is subvertical (Figure 3d). Hornfels textures can be recognized within 5- to 10-m-wide zones in the Permian country rocks (sandstones), and in 200-m-wide skarn zones along the northeastern contact. The bedding of the country rocks is tilted outward in the southwest and inward in the northwestern parts 

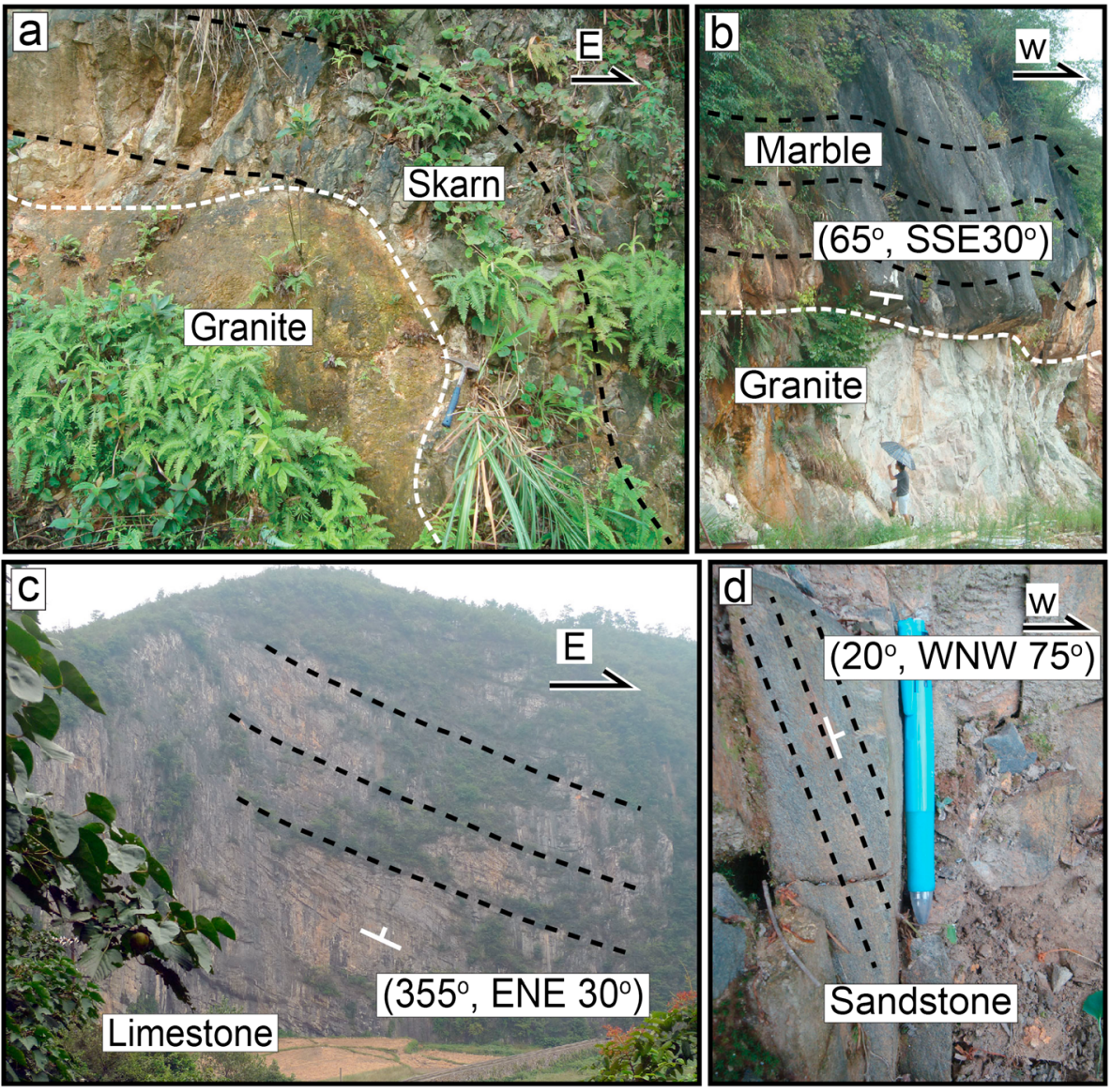

Figure 3. The field photographs of the (a) northern, (b) southern, (c) eastern, and (d) western contact zones between the pluton and its wall rocks. The black dashed lines highlight bedding in the country rocks, while the dashed white lines mark the contact between granites and country rocks.

of the pluton that may be an inherited Triassic deformation feature or a feature developed during pluton emplacement (Figure 3d). Locally, the country rock bedding is irregular and bent close to the contact with the granite (Figures 3a and 3b). However, both the skarn and hornfels contact zones lack foliations or lineations.

Contacts between the facies I and facies II granites are irregular wavy and gradational over $\sim 10 \mathrm{~cm}$, and they are characterized by a moderately steep dip $\left(\sim 30-60^{\circ}\right)$ toward the pluton margin (Figures $4 \mathrm{e}$ and 4f). The facies II granites are fine-grained and biotite-rich within $\sim 5 \mathrm{~cm}$ of the contact, while the facies I granites show no obvious textural or mineralogical zonation toward the contact (Figure 4e). Contacts of the facies III with facies I and II are not observed. All three granite facies lack obvious magmatic foliations and lineations. K-feldspar megacrystals and coarse-grained minerals including amphibole, plagioclase, and biotite show no preferred orientation in the center of the pluton or close to its margins (Figures 4a-4c). Mafic, hornblende-rich, or biotite-rich schlieren have not been observed, while some mafic microgranitoid enclaves locally occur in the facies I granites. The microgranitoid enclaves are generally $\sim 5$ to $50 \mathrm{~cm}$ in maximum dimension, with aspect ratios of 0.4 to 0.8 , and mostly $0.7 \pm 0.1$ (Figure S1 in the supporting information). They are only weakly elongated, showing no preferred orientation, and they are also irregularly distributed in the pluton.

Anisotropy of Magnetic Susceptibility measurements were carried out because they provide quantitative structural data that may not be gained in classical field studies, often providing key insights for constraining magma emplacement process (e.g., Morgan et al., 2017). AMS sampling was carried out at 53 sites, located along 6 roads that cover the 3 lithological facies from different parts of the pluton and also the country rocks (Figure 2). The outcrops chosen for AMS analyses all have large exposure (several tens of square meters), 

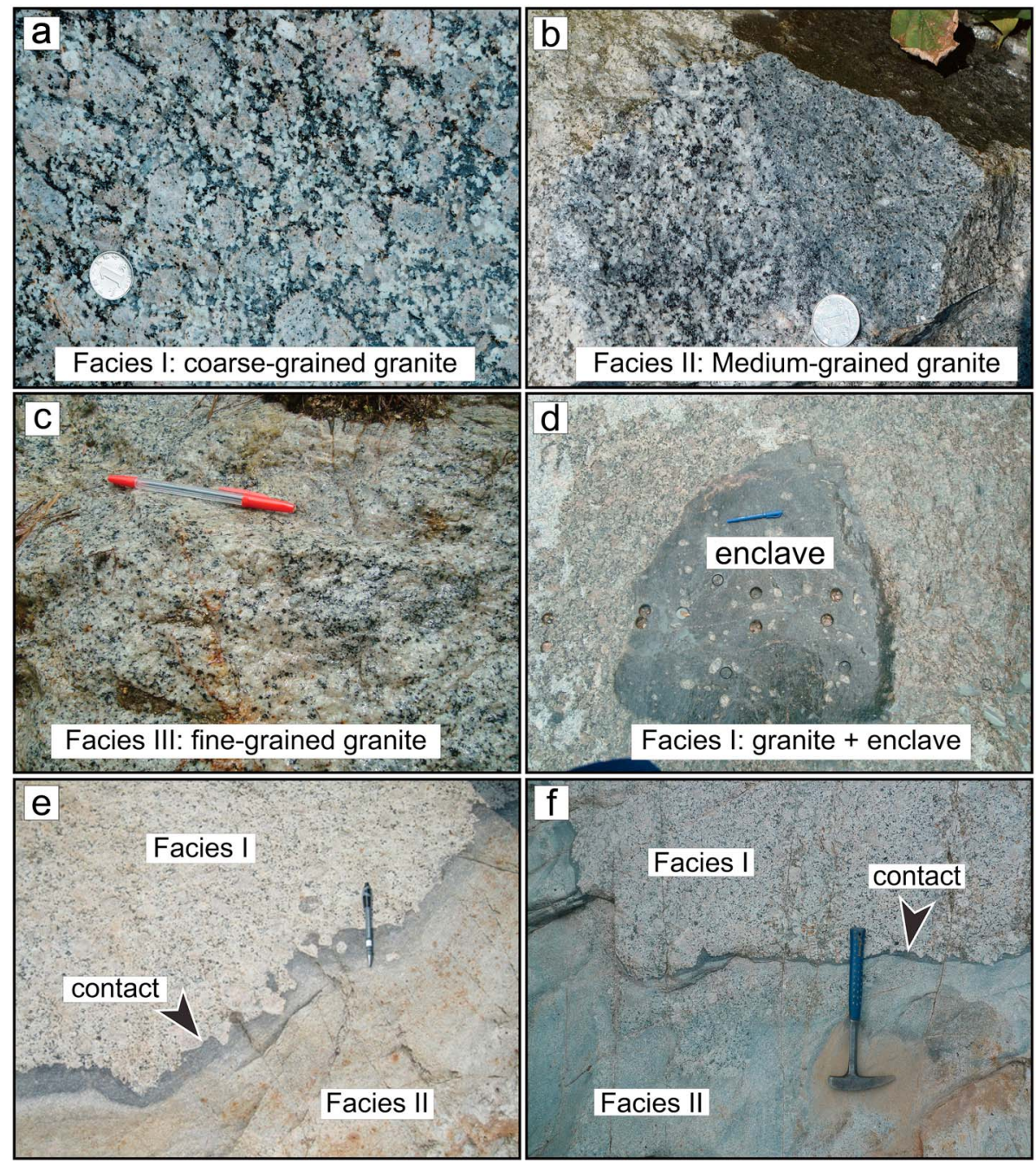

Figure 4. (a-c) Characteristic exposures of facies I, facies II, and facies III granite; (d) a mafic enclave in the facies I granite; (e and f) a typical contact between the facies I and II granites.

which allowed us to collect at least six drill cores at each site. The distance between the sampling sites was $\sim 2 \mathrm{~km}$ (Figure 2).

\section{Methodology and Results}

\subsection{Microscopic Observations}

Five oriented and 20 nonoriented thin sections of facies I, II, and III granites and metasandstone country rocks were used for mineralogical and qualitative textural characterization. Skarn country rocks were not further analyzed as they are severely altered (Figure 3a). The facies I, II, and III granites have typical magmatic fabrics; that is, their main mineral components have euhedral-subhedral habitus, planar grain boundaries, and they also lack high-temperature, intracrystalline deformation features (Figures 5a-5c). Consistent with these observations, none of the minerals shows a preferred orientation on the macro or the microscale, thus lacking a record of obvious foliations or lineations. Plagioclase and K-feldspar are prismatic to subhedral-interstitial, lacking subgrains or deformation twins, while they show well-developed polysynthetic and Carlsbad twinning (Figure 5b). Quartz is subhedral-interstitial, showing evidence for weak high-temperature deformation, such as undulose extinction and chessboard patterns. Sutured grain boundaries or subgrains are not developed. Biotite is characterized by subhedral-euhedral shape and straight cleavage planes with no evidence for bending or kinking (Figures 5a-5c). Magnetite and ilmenite are important accessory minerals 

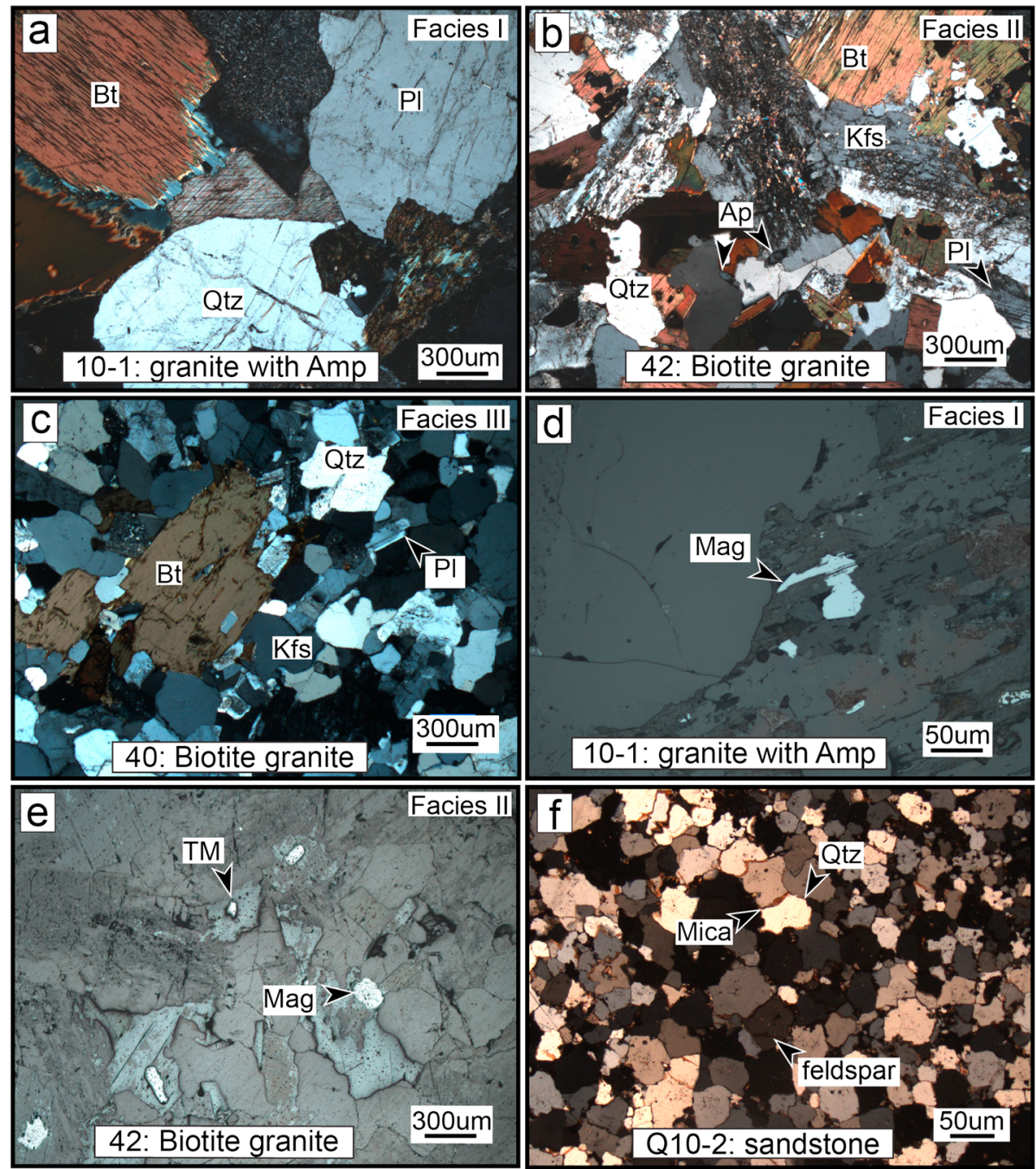

Figure 5. Microphotographs in crossed polarized light of (a-c) facies I, II, and III Qitianling granites; (d and e) microphotographs in reflected light of magnetite in facies I and II granites; and ( $f$ ) microphotograph in crossed polarized light of a Permian metasandstone from within the thermal aureole of the Qitianling pluton. Abbreviations: Ap: apatite, Bt: biotite, Kfs: K-feldspar, mag: magnetite; Pl: plagioclase, Qtz: quartz, TM: titanomagnetite.

(Figures $5 \mathrm{~d}$ and $5 \mathrm{e}$ ). They are commonly intergrown with biotite with their long axis parallel to the biotite cleavage (Figure $5 \mathrm{~d}$ ), or they occur as subhedral interstitial crystals (Figure 5e).

Metasandstone hornfels from the contact zones are characterized by an assemblage of fine-grained, equant quartz, feldspar, and biotite grains (Figure 5f). Andalusite or sillimanite has not been observed. Quartz shows rare sutured grain boundaries, but no undulose extinction or other high-temperature deformation features, indicating that high-temperature annealing took place after weak deformation. Biotite is subhedral to euhedral, free of bending or kinking. The microscopic observations thus reinforce our field observations, highlighting that the Qitianling pluton and its country rocks are devoid of significant intrusion-related brittle or ductile deformation.

\subsection{Magnetic Mineralogical Analysis}

To characterize the carriers of the magnetic susceptibility of our samples for AMS analysis, that is, diamagnetic, paramagnetic, and ferromagnetic minerals, we have performed (1) a thermomagnetic characterization using a KLY3 kappabridge coupled with a CS3 furnace, (2) an isothermal remanence magnetization measurement with an IM30 pulsed magnetizer and a JR5 spinner magnetometer at the Institut des Sciences de la 

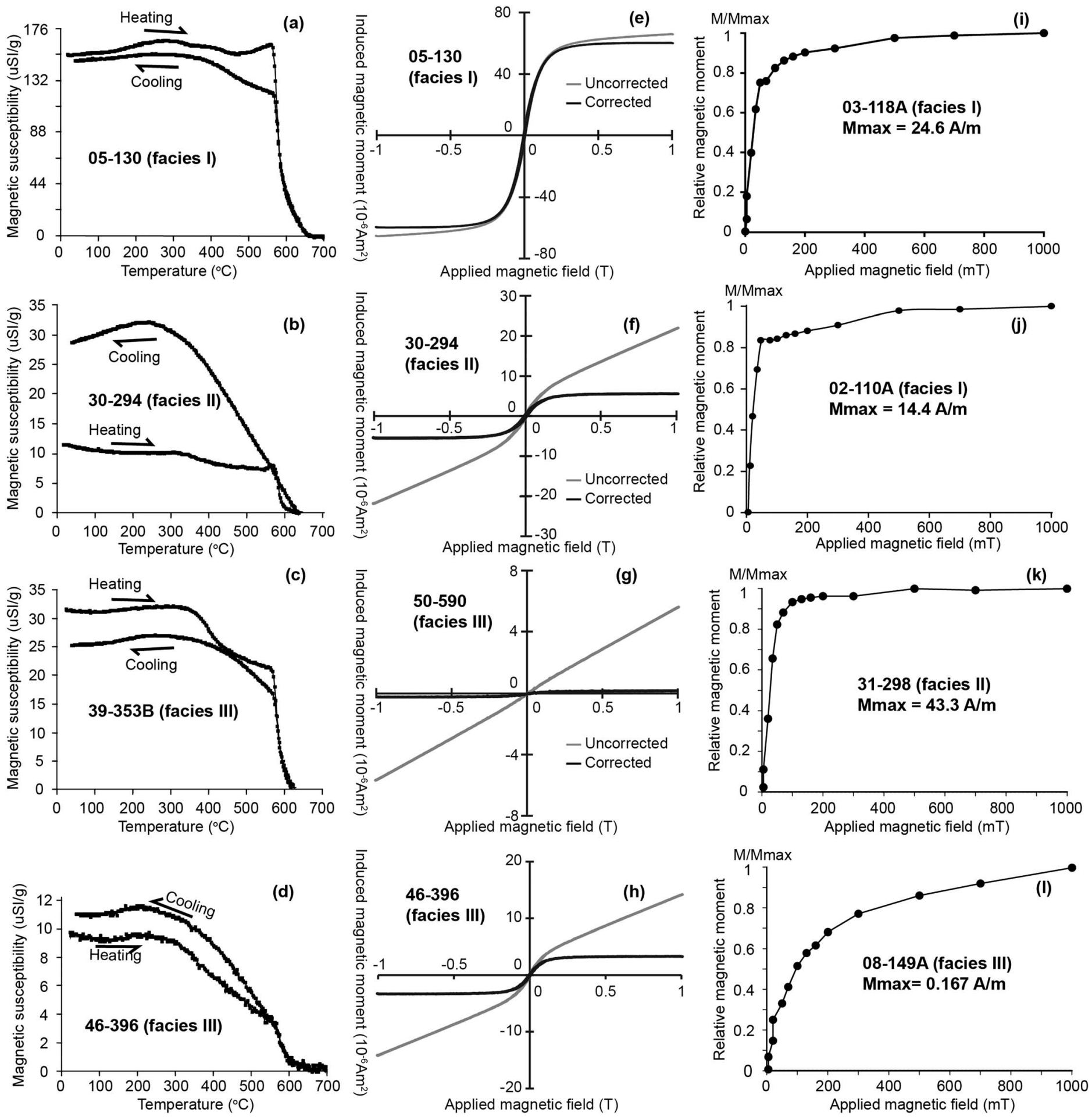

Figure 6. Magnetic mineralogical analyses of the three facies of the Qitianling pluton.

Terre d'Orléans, and (3) magnetic hysteresis loop characterization using a vibrating magnetometer at the Laboratoire de Paleomagnétisme of the Institut de Physique du Globe de Paris.

A total of 10 fresh samples from the three granite facies were chosen for magnetic mineralogical analysis. Figure 6 shows representative results. The thermomagnetic measurements on all granites facies show a rapid drop of the magnetic susceptibility at $580^{\circ} \mathrm{C}$ (Figures $6 \mathrm{a}-6 \mathrm{~d}$ ), indicating the presence of magnetite. The facies 


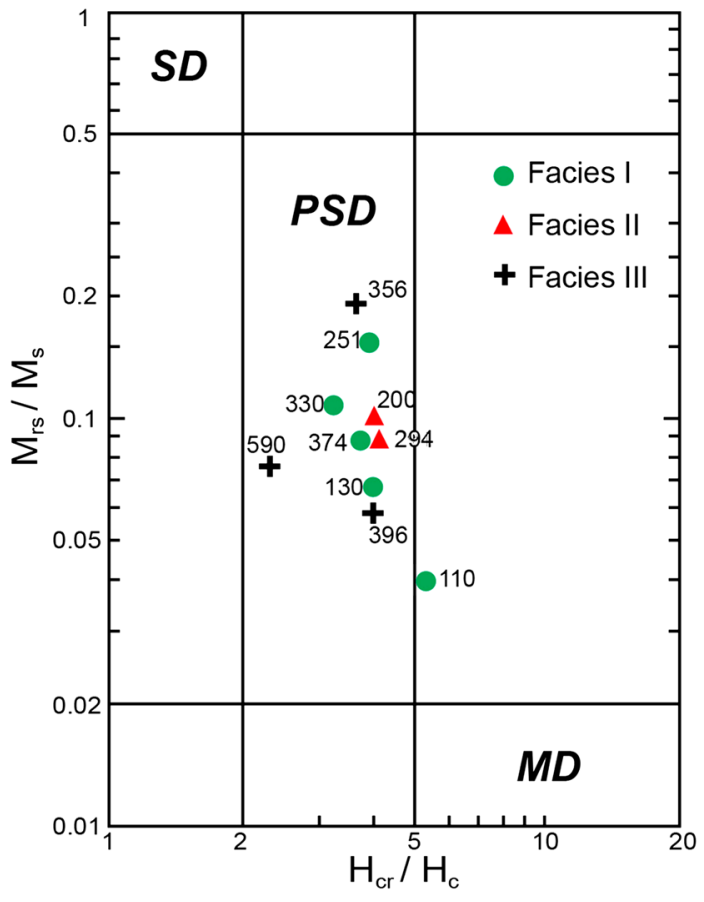

Figure 7. Day plot of hysteresis parameters for the Qitianling pluton. Mrs: the saturation intensity of magnetic remanence, Ms: the saturation intensity of induced magnetization, $\mathrm{Hcr}$ : the coercivity of magnetic remanence, $\mathrm{Hr}$ : coercivity of the measured sample. SD: single domain, PSD: pseudo-singledomain, MD: multidomain.
II and III samples show an obvious continuous increase in susceptibility upon cooling (owing to oxidation reactions; Figures $6 \mathrm{~b}$ and $6 \mathrm{~d}$ ), and a gradural decrease of the magnetic susceptibility between $210{ }^{\circ} \mathrm{C}$ to $580^{\circ} \mathrm{C}$ (Figure $6 \mathrm{~d}$ ), indicating the presence of titano-magnetite in the granite. The hysteresis curve of the facies I granites (Figure 6e) shows a dominance of ferromagnetic susceptibility (magnetite), and those of the facies II and III granites (Figures $6 \mathrm{f}-6 \mathrm{~h}$ ) highlight that the varying content of ferromagnetic minerals and the magnetic susceptibility predominantly relates to the presence of paramagnetic minerals (e.g., hornblende, biotite, and feldspar) and that magnetite is a comparatively subordinate carrier. Sudden saturation of the isothermal magnetic remanence at $\sim 50 \mathrm{mT}$ is characteristic for the facies I and II granite samples (Figures 6i-6k), indicating the preservation of ferromagnetic minerals. The facies III samples, which have the lowest magnetic remanence intensity among all samples, show gradual saturation (Figure $6 \mathrm{l}$ ), suggesting that the paramagnetic minerals are probably the major magnetic carriers. Figure 7 plots all the hysteresis loop measurements and reveals that the majority of magnetite of the analyzed samples is in the pseudo single-domain zone (Day et al., 1977; Dunlop, 2002). This implies that the principal axis of the magnetic susceptibility ellipsoid concurs with the major morphological axis of minerals, thus recording magmatic or tectonic foliations and/or lineations (e.g., Borradaile \& Mothersill, 1984).

\subsection{AMS Parameters}

The AMS measurements were carried out with a KLY3 Kapprabridge at the Institut des Sciences de la Terre d'Orléans. The intensity of the bulk magnetic susceptibility of the three granite facies decreases from facies I to III with mean intensities of $35.06 \times 10^{-4} \mathrm{SI}, 27.25 \times 10^{-4} \mathrm{SI}$, and $2.94 \times 10^{-4} \mathrm{SI}$, respectively (Figure 8a). All measured samples have a relatively low anisotropy degree except for site $30\left(P_{J}<1.12\right.$; Figure $\left.8 \mathrm{~b}\right)$. The bulk magnetic susceptibility $(\mathrm{Km})$ and the degree of anisotropy $\left(P_{J}\right)$ are not correlated (Figure $8 \mathrm{~b}$ ). The shape parameter $(T$ ) mainly ranges between -0.64 and 0.88 (Figure $8 \mathrm{c}$ ), showing a dominant oblate shape $(\sim 80 \%)$ for the magnetic fabrics.

\subsection{AMS Results}

Figure 9 shows the AMS results for all 318 specimen from 53 sites of the Qitianling pluton. Detailed data are provided in Table S1. At the site scale, the poles of the magnetic foliation ( $k 3)$ are highly grouped. The majority of the granite specimen from 30 sites show horizontal to subhorizontal foliations (Figure 9a) with dip angles of $\sim 9^{\circ}$ to $23^{\circ}$ (Table S1). These foliations characterize most of the exposure of the pluton including outcrops of the central part as well as outcrops close to pluton margins (Figure 9b). Sites located at the eastern, northeastern, and southwestern margins of the pluton, however, show outward dipping magnetic foliations.

Specimen from nine sites have steep to moderately steep magnetic foliations (dip angles $>60^{\circ}$ ). Four of these sites $(23,24,27$, and 46$)$ are close to map-scale fault planes, two sites (38 and 52) are located at the contact between facies II and facies III granites, while two other sites (43 and 53) are $>3 \mathrm{~km}$ away from apparent fault planes but close to facies contacts, and one additional site (44-2) is characterized by subvertical magnetic foliations. In addition, these foliations have variable orientations with a high standard deviation of $37^{\circ}$ (Table S1). The remaining 13 sites have moderately steep foliations with dip angles between $31^{\circ}$ and $60^{\circ}$ and mostly $<45^{\circ}$ with irregular dip directions. These sites are located (1) near granite-country rock contacts (sites 01, 03, 04, and 10), (2) near facies contacts (sites 08 and 45), or (3) in fault areas (sites 07, 15, 16, 18, and 22), otherwise (4) in the central parts of the facies II granites (sites 30 and 37). The magnetic lineations (k1) are highly variable. Within single outcrops, lineations measured in different specimen vary significantly; consequently, the site mean declination ( $\mathrm{k} 1$ ) values have standard deviations of $\sim 7^{\circ}$ to $\sim 75^{\circ}$ ( $n=5-10$; black squares in Figure 9 a and Table S1). Gently plunging lineations $\left(0-30^{\circ}\right)$ are predominant, but steeply plunging ones $\left(>30^{\circ}-90^{\circ}\right)$ do occur (Figure $\left.9 \mathrm{c}\right)$. Some, but not all of the outcrops with moderate $\left(30^{\circ}-60^{\circ}\right)$ to steep $\left(60^{\circ}-\right.$ $90^{\circ}$ ) foliations, show steep lineations. Occasionally, neighboring outcrops show subparallel average lineation 

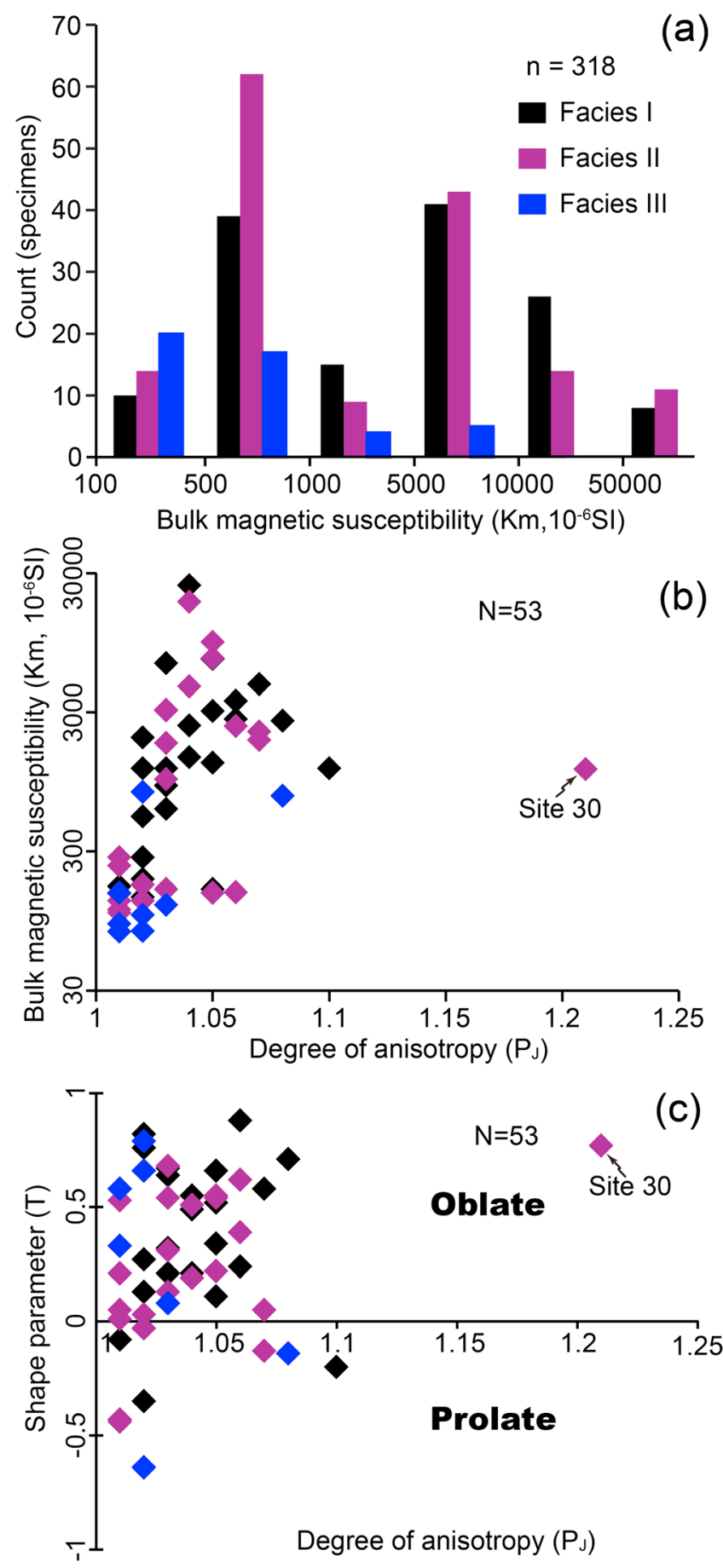

Figure 8. (a) Distribution of bulk magnetic susceptibility of the three granite facies in the Qitianling pluton; (b and c) parameters of anisotropy of the magnetic susceptibility. orientations, but this pattern is highly variable, where lineation orientations from adjacent outcrops may also vary significantly (by $>45^{\circ}$ ). The locally present microgranitoid enclaves show magnetic foliations and lineations subparallel to these of their host granites (e.g., 03-1 and 03-2 in Figure 9a).

\subsection{Gravity Modeling}

Gravity modeling has been successfully applied to explore subsurface structures on the basis of gravity anomalies that reflect the density contrasts between crustal lithologies (e.g., Martelet et al., 2013; Vigneresse, 1990). We have applied this method to characterize the shape of the unexposed part of the Qitianling pluton. The primary data that we have used include (1) Bouguer gravity anomaly data, (2) density values of major rock types, and (3) a digital elevation model of the Qitianling pluton and its surrounding area. The Bouguer gravity anomaly data are from the Chinese Bouguer gravity anomaly database, which are acquired, treated, and provided by the geological survey center of China, that is, (1) a 1:200,000 original Bouguer gravity anomaly map of the Qitianling pluton and (2) a $1: 2,500,000$ Bouguer gravity anomaly map of the Hunan province covering the Qitianling pluton and its country rocks. Density values of the facies I to III granite samples were measured at Nanjing University using a Matsuhaku Electronic Densimeter GH-300. One granite sample from each sampling site was measured twice at a density precision of $0.001 \mathrm{~g} / \mathrm{cm}^{3}$. Fifty-three samples were measured, which show a closely comparable density (i.e., $2.62 \pm 0.01 \mathrm{~g} / \mathrm{cm}^{3}$; Table S2). Their mean density value of $2.62 \mathrm{~g} / \mathrm{cm}^{3}$ was therefore used for modeling the gravity anomaly of the pluton. The densities and thicknesses of the country rock previously measured by the Chinese Geological Bureau of Hunan Province (BGMRHN, 1988) were also used in this study (Table S3). The results show that the Silurian and the Ordovician strata with similar lithologies (flysch-like metasandstones, metashales, and metacarbonates) have densities comparable to those of the Devonian strata (carbonates and terrigenous sediments). Due to the limited thickness of the Silurian and Ordovician strata in the study area (BGMRHN, 1988), an identical density value of $2.68 \mathrm{~g} / \mathrm{cm}^{3}$ was adopted for all the above-mentioned country rocks of the Qitianling pluton (Figure 10 and Table S3). For the same reasons, density values of 2.54 and $2.70 \mathrm{~g} / \mathrm{cm}^{3}$ were used for the Jurassic-Cretaceous strata, and for the Cambrian to Neoproterozoic strata, respectively (Table S3). The digital elevation model for the Qitianling area, with a resolution of $90 \mathrm{~m}$ at the equator, has been downloaded from http://srtm.csi.cgiar.org/.

The original Bouguer gravity data set consists of regional and long wavelength signals that include depth and surface signatures. To infer the subsurface shape of the pluton, regional long wavelength signals of the Bouguer anomaly corresponding to the deepest density contrasts were removed. The 1:2,500,000 regional Bouguer gravity anomaly map of Hunan province was used to calculate the long wavelength gravity anomaly trend using a low-pass Butterworth filter with cutoff wavelengths of 50 , 70,100 , and $150 \mathrm{~km}$. Therein, the 100-km wavelength cutoff was chosen as the best regional trend as the residual Bouguer anomaly (original Bouguer anomaly minus regional trend) best matches gravity anomalies and surface geological features.

In the residual Bouguer gravity anomaly map (Figure 10), the Qitianling pluton shows a negative anomaly with an anomaly center in its southwestern part (Figure 10). The country rocks show variably positive anomalies. Seven independent cross sections with 12 intersections were designed for gravity modeling (solid white 


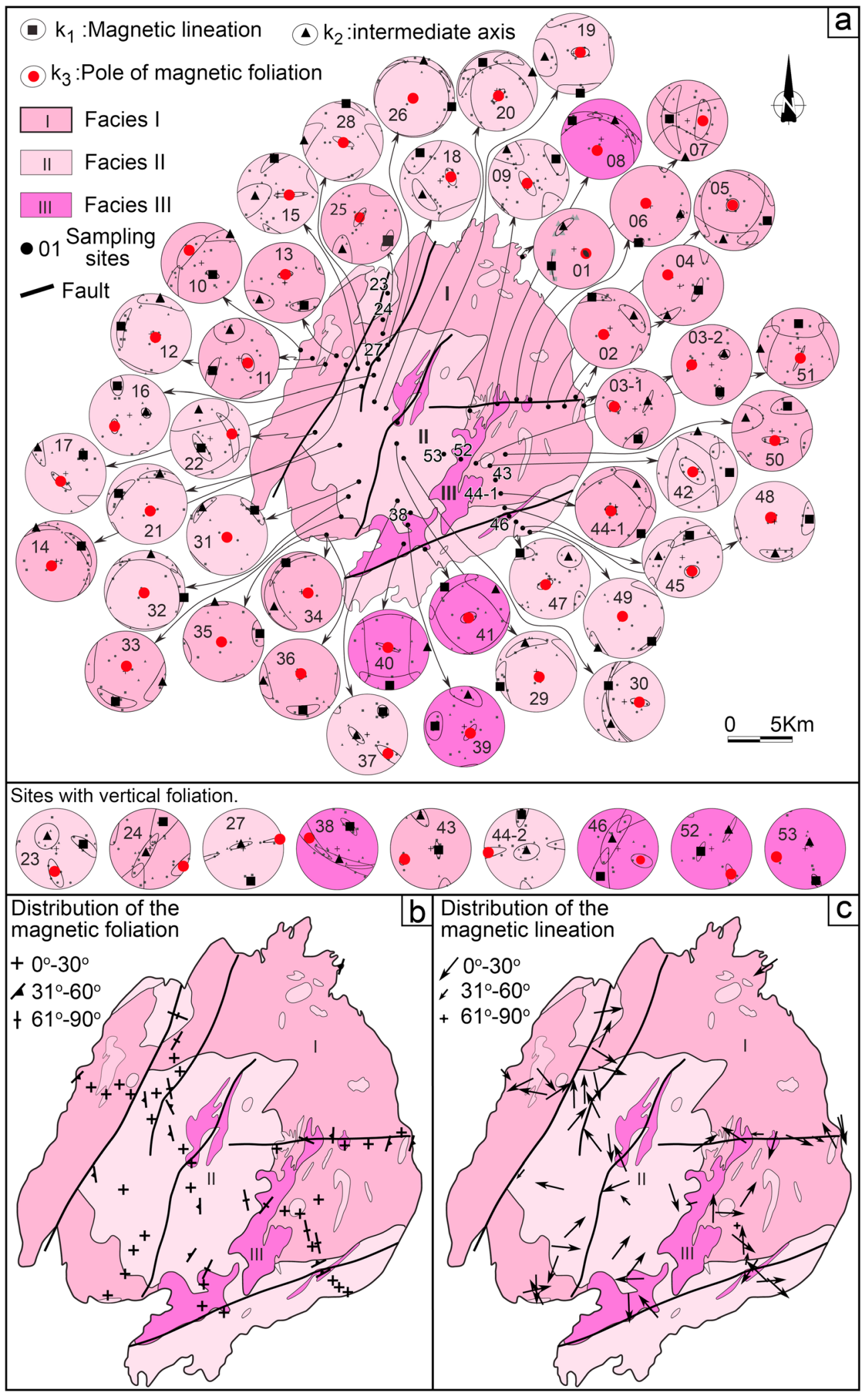

Figure 9. (a) Anisotropy of Magnetic Susceptibility results for each sampling site in the Qitianling pluton and (b and c) distribution of the average magnetic foliations (K3) and lineations (K1) for each site. Averages were determined for 5-10 measurements per site. The small inset numbers are site numbers referred to in the text. 

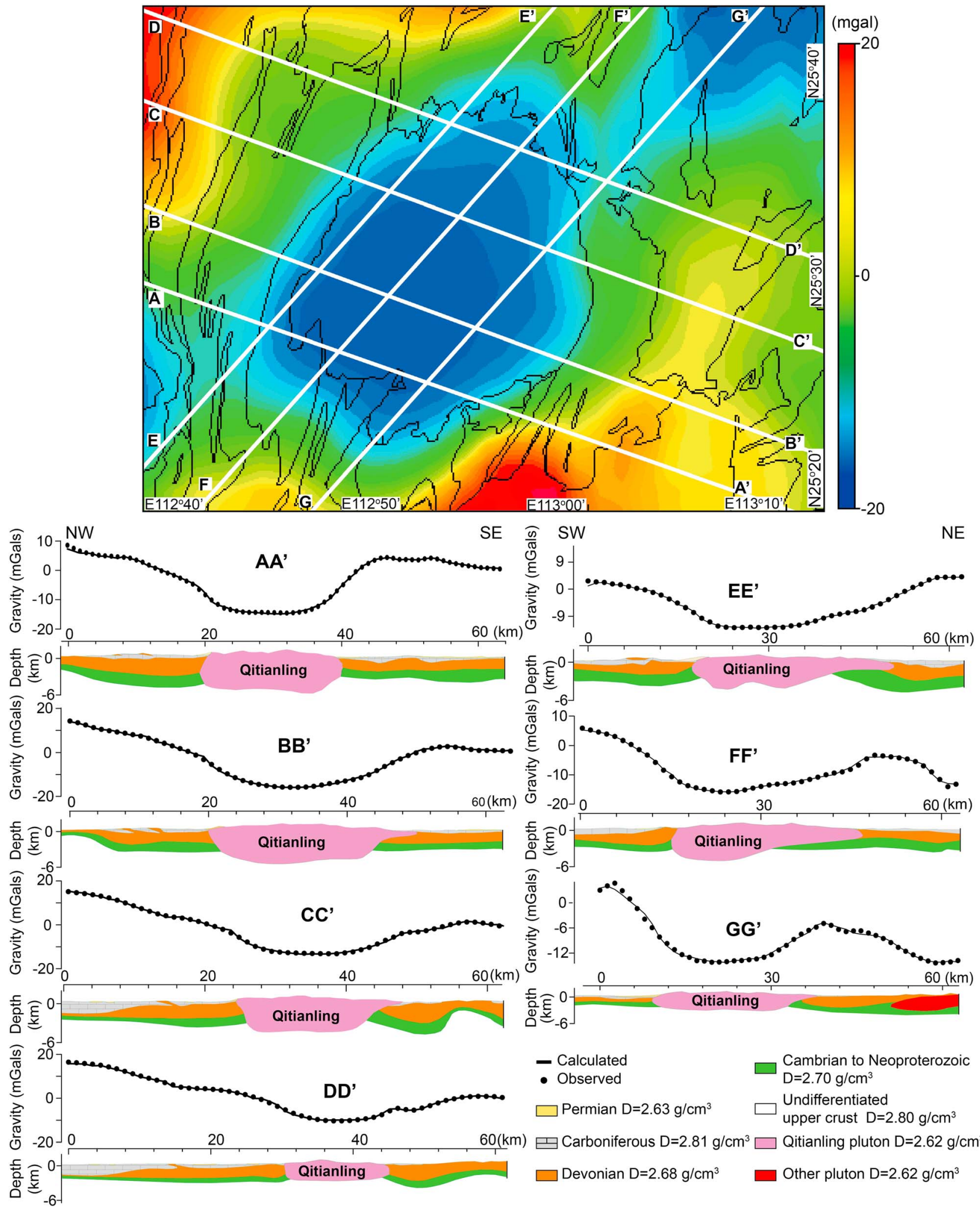

Figure 10. Residual Bouguer gravity anomaly map for the Qitianling area and interpreted profiles of Bouguer gravity anomalies. The thin black lines in the map outline surface geological boundaries (see Figure 2 for comparison); the heavy white lines mark the location of the gravity modeling profiles. Profiles $\mathrm{AA}^{\prime}, \mathrm{BB}^{\prime}, \mathrm{CC}^{\prime}$, and $\mathrm{DD}^{\prime}$ extend in NW-SE direction, perpendicular to the Triassic fold axes developed in the wall rocks. Profiles EE', $\mathrm{FF}^{\prime}$, and $\mathrm{GG}^{\prime}$ extend in NE-SW direction, parallel to the Triassic fold axes of the wall rocks. The black dots and lines of the profiles are plots of measured residual Bouguer gravity anomaly values and calculated gravity anomalies, respectively. 
lines in Figure 10), including four NW-SE striking profiles, which are oriented perpendicular to the strike of the regional Triassic fold-thrust belt. The other three profiles were modeled in NE-SW direction, that is, parallel to the regional tectonic axes. Subsequently, numerous repeated attempts were made to match all the profiles to have similar depth at the intersection. Altogether, the seven profiles show that the pluton has (1) a flat-top which is suggested by the low-angle $\left(<20^{\circ}\right)$ intrusive contact, in particular along the NE-SW-striking profiles ( $\mathrm{EE}^{\prime}, \mathrm{FF}^{\prime}$, and $\mathrm{GG}^{\prime}$ in Figure 10); (2) a maximal thickness of $\sim 5 \mathrm{~km}$ in the southeastern part and a thickness that progressively decreases northeastward to a minimum of $\sim 1 \mathrm{~km}$; (3) a roughly symmetric geometry in NW-SE direction (profiles $\mathrm{AA}^{\prime}, \mathrm{BB}^{\prime}, \mathrm{CC}^{\prime}$, and $\mathrm{DD}^{\prime}$ in Figure 10); (4) a flat bottom without a significant relief, except for profile $\mathrm{EE}^{\prime}$ that is likely affected by gravity signals from the country rocks; and thus (5) an overall tabular (laccolith, sill or lopolith) shape.

\section{Discussion}

\subsection{Origin of the Magnetic Fabrics}

In the Qitianling pluton, 96\% of the characterized sites have a degree of anisotropy $\left(P_{\jmath}\right)$ lower than 1.08 (Figure $8 \mathrm{~b}$ ). Approximately $80 \%$ of the measured magnetic fabric ellipsoids plot in the oblate field (Figure 8c). Microscopic observations indicate that magnetite is predominantly subequant (Figure 5e), but some magnetite grains that occur subparallel to the biotite cleavage planes show an oblate shape (Figure 5d), accounting for the oblate magnetic fabrics. The prolate magnetic fabrics with obvious negative $T$ values range from -0.13 to -0.64 (Figure 9 , sites $9,10,22,27,38,39$, and 47 ), which may record magma flow at some sites close to the boundaries of the different granite facies or granite and country rock contacts. Evidence for deformation-driven (1) synmagmatic crystal re-orientation or (2) subsolidus recrystallization is lacking. Considering field and thin section observations, we consider the magnetic fabrics of the Qitianling pluton as primary magmatic ones (e.g., Borradaile \& Henry, 1997; Tarling \& Hrouda, 1993). Thus, we suggest that those fabrics developed during cooling and crystallization of the magma without contribution from synor postmagmatic tectonics. This inference is in agreement with studies from other plutons (Byerly et al., 2016; de Saint-Blanquat et al., 2001).

\subsection{Emplacement Into Ductile Crust}

Amphibole geobarometry estimates suggest that the Qitianling pluton was emplaced at $\sim 3.6 \pm 0.9 \mathrm{kbar}$ (Zhao et al., 2005). The aluminum content of magmatic hornblende is sensitive to the pressure (Hammarstrom \& Zen, 1986; Hollister et al., 1987). The application of the Al-in-hornblende barometer requires that the hornblende grains are intergranular and their compositions are collected from the edge of the grains, indicating that the magma was close to the solidus, and in equilibrium with a multiphase assemblage (Hollister et al., 1987). For the Qitianling case, these conditions are fulfilled, and we propose that the geobarometric estimate records magmatic crystallization and emplacement pressure. We propose that the geobarometry result is equal to the emplacement pressure. Assuming a lithostatic pressure gradient of $3 \mathrm{~km} / \mathrm{kbar}$ (van der Pluijm \& Marshak, 2004), the current exposure of the Qitianling pluton should thus have been originally emplaced at midcrustal depths of 9 to $14 \mathrm{~km}$.

Accurate constraints on the temperatures of the country rocks during the emplacement of the Qitianling pluton are unfortunately lacking. If we assume a normal geothermal gradient of $30{ }^{\circ} \mathrm{C} / \mathrm{km}$ (van der Pluijm \& Marshak, 2004), then the temperatures of the country rocks prior to emplacement and away from thermally affected pluton-country rock zones can be estimated to have been $\sim 270-420^{\circ} \mathrm{C}$ and $\sim 420-570{ }^{\circ} \mathrm{C}$ at depths of $\sim 9-14 \mathrm{~km}$ and $\sim 14-19 \mathrm{~km}$, respectively, corresponding to the reconstructed paleo depths of the top and the bottom of the pluton (Figure 10). Considering the widespread occurrence of Jurassic intrusions in southeast China and the study area, a higher geothermal gradient $\left(>30^{\circ} \mathrm{C} / \mathrm{km}\right.$ ) seems possible and could have certainly prevailed in the thermally affected pluton-country rock contact zone. At the inferred or higher temperatures, ductile deformation of the quartz-rich country rocks would have been possible, even at high or moderately strain rates (i.e., at $10^{-9} \mathrm{~s}^{-1}$ and below strain rates of $10^{-12}$; e.g., Kruhl et al., 2007).

At the exposure level, the Qitianling pluton appears to have significantly heated its country rocks, as there is no evidence for partial melting, even at the immediate contact, and the thermal aureole is very narrow, generally about $20 \mathrm{~m}$ to locally $200 \mathrm{~m}$ wide. Evidence for significant ductile deformation in the form of foliation or lineation in this zone is also absent. The coarsely sutured grain boundaries of quartz in the country rocks 
along the contact zone indicate that thermal annealing at $>350-400{ }^{\circ} \mathrm{C}$ followed weak ductile deformation (e.g., Passchier \& Trouw, 1998). The lack of evidence, that is, preferred mineral orientation, for any significant syn-magmatic ductile deformation in the country rocks of the pluton, the gently outward dipping contact of the wall rocks, the irregular geometry of the pluton, and the lack of regional syn-magmatic deformation, further highlights that (1) the displacement of the country rocks producing the space for the Qitianling pluton must have been predominantly vertical, that is, affected the roof zone or the floor of the intrusion, and (2) no significant regional deformation took place during the construction of the Qitianling pluton in the late Jurassic; this is also in agreement with the regional tectonic observations of Shu, Faure, et al. (2011).

As highlighted above, the study area underwent long and multi-stage tectonism from the Neoproterozoic to the Triassic, while regional-scale evidence for significant and consistent deformation is lacking. Especially the Phanerozoic intracontinental deformation events, however, resulted in a highly and deeply fractured crust (Wang et al., 2013, and references therein). The abundant and large-scale pre-Jurassic fractures may have served as channels that facilitated magma ascent. Emplacement may have commenced by dyking, while later magma pulses deflected into sill- to lopolith-like sheet when the magma meet the "traps" in the highly fractured crust as mentioned in (Gudmundsson, 2011). Large-scale, subvertical fractures may have also allowed for efficient fluid percolation and thus for efficient heat removal from the intrusions, so that contact metamorphism and thermal aureroles remained limited. We suggest in summary that the Qitianling pluton was emplaced into a highly fractured middle crust and that none of its country rocks have experienced significant ductile deformation during magma emplacement.

\subsection{Sill- to Lopolith-Like Emplacement}

The Qitianling pluton has a subcircular surface exposure, but the Bouguer gravity anomaly data (Figure 10) indicate that the pluton shows a slight subsurface elongation in NE-SW direction with a length ( 30 km)/ width $(\sim 23 \mathrm{~km})$ ratio of $\sim 1.3: 1.0$. The Bouguer gravity anomaly data further reveal that the pluton extends to a depth of $\sim 6 \mathrm{~km}$ with a flat bottom and shallow to moderately steep-dipping sidewalls. Roof pendants are not exposed inside of the pluton, and we therefore have no direct control on the top shape of the pluton. However, the mostly subhorizontal, yet gently outward-dipping magnetic foliations (dip angles $<30^{\circ}$ at sites $01,02,03,10,11,36,48$, and 49 ; Figure 9a) suggest that the current topographic surface is close to the roof of the pluton. Thus, the overall geometry and the magnetic foliations indicate a tabular shape for the Qitianling pluton (Figure 10).

The subhorizontal foliations may have developed by subvertical magma flow against a roof at the head of a diapir (Kratinová et al., 2006), but emplacement of the Qitianling pluton as a diapir is unlikely considering (i) its overall oblate geometry, (ii) its horizontal to subhorizontal magnetic foliations developed over an elevation range of $\sim 800 \mathrm{~m}$ (Figure 9 and Table S1), and (iii) the lack of significant ductile deformation in the country rocks. The subhorizontal magnetic foliation could have therefore developed by (1) magma flow subparallel to a roof (e.g., Horsman et al., 2009; McNulty et al., 2000), (2) flattening of magma mush against a roof driven by under-accreted magma pulses (McNulty et al., 2000), or (3) vertical gravitational potential energy resulting in partial sagging of overlying rocks or magma mush (Bain et al., 2013).

Emplacement of magmas as sill- or lopolith-like intrusions is typical for middle- to deep-crustal levels, commonly along fractures, faults and/or lithological boundaries in combination with variable degrees of ductile deformation of country rocks or preferential floor sinking (Cruden, 1998; Horsman et al., 2005; Mathieu et al., 2008). Such a mode of emplacement is consistent with the estimated emplacement pressure of $\sim 3.6 \pm 0.9 \mathrm{kbar}$ and paleo-depths of $\sim 9-14 \mathrm{~km}$, and the roughly tabular geometry of the Qitianling pluton. The slight subsurface elongation of the Qitianling pluton in NE-SW direction could imply syn-magmatic country rock displacement, but none of the wall rocks show significant deformation or in fact any variation in deformation intensity in different sections (Figure 2). Additionally, any regular or preferred orientation of magnetic lineations cannot be recognized (Figure 9c). Therefore, syn-magmatic deformation or regional tectonic stress is unlikely to have produced the NE-SW elongation of the pluton. Preexisting structures, that is, generally NE-SW-striking lithological boundaries and regional pre-Jurassic fold and/or fault planes, produced by polyphase tectonic events since the Neoproterozoic (Shu, 2012; Wang et al., 2013), could have controlled and indeed facilitated emplacement in NE-SW direction. 


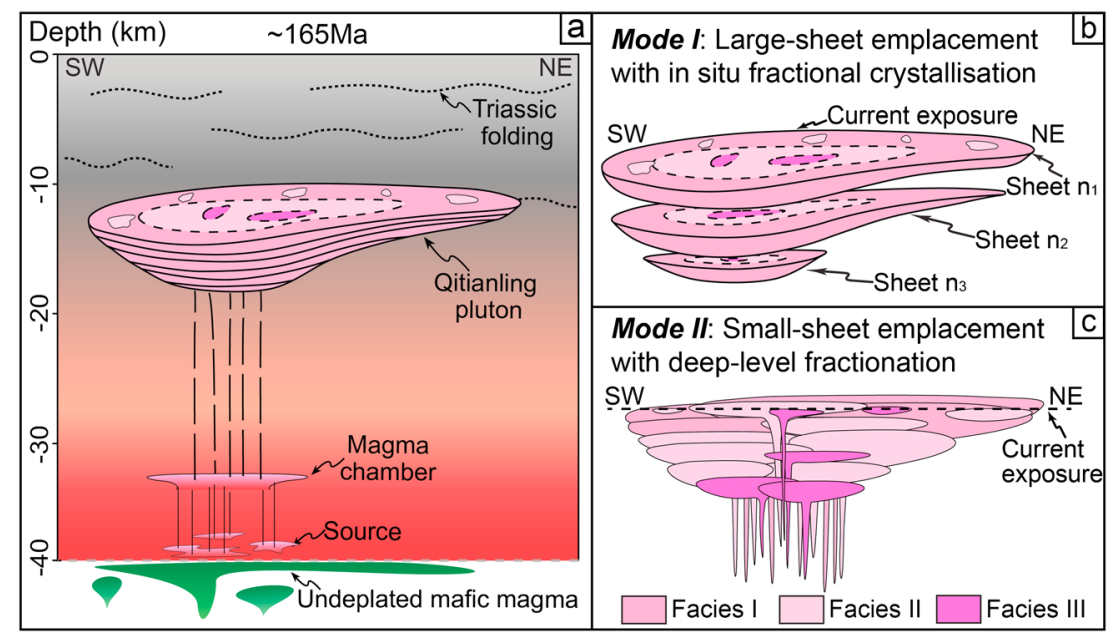

Figure 11. (a) Schematic sketch summarizing the original intrusion setting; (b) downward accretion of multiple sill-like or lopolith-like magma injections in multiple large-diameter sheets that fractionated in situ to form the facies I, II, and III granites and repeated for several times to construct the Qitianling pluton; (c) multiple large- to small-diameter sheets, where the intrusion of facies I magma was followed by the intrusion of facies II and then facies III magma.

\subsection{Incremental Magma Emplacement}

In all 72 visited outcrops, only one direct internal contact between the facies I and II granites was observed, despite concentrated efforts near mapped facies boundaries, while similar contacts have also been described by Zhu et al. (2009) from other locations. The scarcity of outcrop-scale contacts may indicate that they were obliterated by remelting or recrystallization during subsequent injections of magma and/or that most injected magma sheets were significantly larger than the outcrop scale (i.e., $>10 \mathrm{~m}$ in vertical and $>100 \mathrm{~m}$ in horizontal dimension), which would have reduced the likeliness that contacts are exposed (e.g., Coleman et al., 2004; John \& Blundy, 1993). In the following, we propose two possible conceptual models (Figure 11) to explain the key observations and results from our and previous studies, including (a) undeformed country rocks with narrow thermal aureoles characterized by hornfels metasandstone ( $10 \mathrm{~m}$ wide) or skarn ( $200 \mathrm{~m}$ wide) along the contacts of the pluton; (b) distribution of three granitic facies (I, II, and III) with continuous whole-rock compositional and mineralogical variation; (c) the irregular wavy contact between facies I and facies II with fine-grained, biotite-enriched zones in the facies II granite; (d) the commonly subhorizontal and only locally steep to moderately steep magnetic foliations in all three granitic facies; (e) predominantly subhorizontal yet variably oriented magnetic lineations; (f) the scarcity of exposed dykes; (g) the significant zircon U-Pb age range of the exposed granites; and ( $\mathrm{h}$ ) a subcircular sill- or lopolithlike 3-D pluton shape. We consider incremental emplacement as the likely process, which is favored by the vast majority of current pluton emplacement models based on field, geochemical, and geochronological data and numerical modeling data (e.g., Annen et al., 2015; Coleman et al., 2004; Deniel et al., 1987; Scaillet \& Searle, 2006). The large spread in crystallization ages determined for the exposed Qitianling granites (i.e., 148-163 Ma) is consistent with incremental emplacement, but we critically discuss the record of the available age data and the need for further detailed investigation.

\subsubsection{Model 1: Large-Sheet Emplacement, In Situ Fractionation}

Large individual sheets emplaced in tabular intrusions are recognized to have radii of up to $\sim 25-50 \mathrm{~km}$ (Annen et al., 2015; Caricchi et al., 2014). The exposed section of the Qitianling pluton may thus represent large, subcircular magma sheets constructed by continuous magma pulses, with a radius of $\sim 20 \mathrm{~km}$ (Figures 2a and 11b). In situ fractionation can account for the continuous whole-rock compositional and mineralogical variations (Bai et al., 2005; Deng et al., 2005; Xie et al., 2010) and the overall subcircular mapscale facies distribution (Figure 2). The zoning from the facies I (hornblende-biotite) granites exposed along the margins of the pluton over the facies II (biotite-hornblende) granites to the facies III (biotite) granites occurring in the center of the pluton could record inward cooling and fractionation.

A majority of the magnetic foliations and lineations is subhorizontal and may indicate subhorizontal magma flow within the sheet or alternatively suggest magmatic flattening against subhorizontal roof and floor zones. 
The generally subhorizontal magnetic foliations also suggest that magma emplacement and crystallization most likely took place during a period of tectonic quiescence. The variation of magnetic lineation orientation on a small scale, that is, often between outcrops, may reflect uncertainties of the measurements rather than true differences or fabric relaxation subsequent to magma flow. Some of the steep to moderately steep magnetic foliations (and some lineations) occur close to map-scale fault zones in relatively altered granites, and we therefore consider that these magnetic foliations (lineations) have been overprinted by recrystallization during late-stage hydrothermal alteration, as strong chloritization of biotite and amphibole are evident in hand specimen and in thin section. Other steep to moderately steep magnetic foliations may indicate the existence of undetected/unmapped fault zones, or local zones in which magma flowed subvertically, for example, along surfaces where magma locally slumped or upwelled. The exposed contacts between facies I and facies II with moderately steep dip angles may equally represent such local vertical magma flow (slumping or upwelling) of a comparatively crystal-poor, more evolved magma (II) against a relatively rigid, more mafic magma mush (facies I). The concentration of biotite in the facies II granites along the contact may record flow-zoning (e.g., as in biotite-rich schlieren).

The large zircon U-Pb age range (163-146 Ma) of the Qitianling pluton (Zhu et al., 2009) cannot be explained by in situ crystallization of one magma sheet, as thermal modeling results suggest that the crystallization of incrementally emplaced granitic sheets with thicknesses of hundreds of meters may take place within several hundreds of thousand years (Annen et al., 2006, 2015; Blundy \& Annen, 2016). However, some of the range in the crystallization ages may relate to analytical errors (i.e., ages determined by LA-ICPMS method; Table 1 of Zhu et al., 2009), while age data determined by high precision SHRIMP and CA-ID-TIMS are limited (Table S4). The majority of samples (mainly facies II granites) define an age peak at 155 Ma (Li et al., 2005; Zhu et al., 2009). The facies I granites appear slightly older ( 160-163 Ma; Fu et al., 2004; Zhu et al., 2003, 2005, 2009), but several (although not all) samples overlap within error with the ages of the facies II granites. Facies III granites appear significantly younger (146-149 Ma; Li et al., 2006; Zhu et al., 2009), but they may have partly re-set ages, as they are discordant and as they were acquired on high-U zircon (e.g., Figure 2 and Table 1 in Li et al., 2006 and Zhu et al., 2009, respectively).

\subsubsection{Model 2: Small-Sheet Emplacement, Deep-Level Fractionation}

The study of Zhu et al. (2009) suggested that the three granite facies of the Qitianling pluton represent magma pulses of variable age, that is, that the facies I to III granites were emplaced at $\sim 160-163 \mathrm{Ma}$, 153-157 Ma, and 146-149 Ma, respectively. Despite the uncertainty of the age of the facies III granites, as highlighted above, the more precise SHRIMP age data nevertheless indicate that the ages of the facies I and II granites differ by an age gap of up to 4 myr (Figure S2 and Table S4; three ages of the facies I and Il granites do not overlap within error). This $\sim 4-m y r$ age gap is far too long for in situ crystallization of one single magma sheet (Annen et al., 2006, 2015; Blundy \& Annen, 2016; Coleman et al., 2004; Matzel et al., 2006; Schoene et al., 2015), but it is in agreement with the exposure of multiple small-scale magma sheets that were emplaced over a few million years. The wavy contacts between the facies I and II granites and their gradation over a few centimeters (our data; Zhu et al., 2009), and the fine-grained, biotite-rich margin of the facies II granite (Figure 3e), may represent a magmatic (quench) contact between a highly crystalline magma mush that crystallized to form the facies I granite and a hotter and relatively crystal-poor magma that crystallized to form the facies II granite. Emplacement of new magma batches into partially crystallized magma mush would have accommodated most of strain and temperature increase, preventing significant strain partitioning into country rocks and resulting in a narrow thermal aureole with weak to no deformation.

Previous studies indicate that individual magma sheets may also have small radii of $\leq 1-5 \mathrm{~km}$ (Annen et al., 2015; Caricchi et al., 2014). For the Qitianling pluton with its radius of $\sim 20-15 \mathrm{~km}$ at surface and at depth, and its subcircular zoning from facies I to III granites, we envision that each facies is made up of some larger and multiple smaller individual sheets, where the facies II and III injections were preferentially injected into the more central and subsolid part of the system. The irregular and NNE-SSW oriented facies boundaries (Figure 4e) in the SE part of the pluton are accounted for in this model. The continuous compositional and mineralogical variation from the facies I to the facies III granites would have to record fractionation of the granitic magmas at deeper crustal level or be source-inherited compositional variation.

The predominantly subhorizontal magnetic foliations and lineations may record subhorizontal magma flow within sheets and/or magmatic flattening against subhorizontal roof and floor zones. The variable magnetic 
lineation directions could have developed by magma flow in different sheets (Figure 8). The steep magnetic foliations and lineations in fault zones may record localized recrystallization as a result of subvertical fluid flow, but the fault zones may also coincide with former subvertical magma transfer zones. The steep and moderately steep ( 30 to $60^{\circ}$ ) magnetic foliations close to the facies I and II boundaries and within the different granite facies may delineate sidewalls (or nearside wall zones) of small-scale, sill-, or lopolith-like injections. Several elongated, small-scale exposures of facies II and III granites (Figure 2) may also represent vertical magma transfer zone. The scarcity of dykes is consistent with possible downward accretion.

\subsection{Magma Feeder Zone(S)}

Previous work has revealed that the Qitianling pluton shows a subcircular geometry in Bouguer gravity and aeromagnetic anomalies (Guo, 2006). This argues against magma supply through one main feeder zone, for example, one laterally extensive dyke. Instead, we envision that the magma was supplied through a number of pipe-shaped conduits comparable in dimension to the elongated facies II granite exposures in the facies I granite or comparable to magma channels described for the lower crust (Bouilhol et al., 2015; Paterson, 2009). To account for the subcircular Bouguer gravity and aeromagnetic anomalies, these pipe-shaped magma feeders must be either small (i.e., unresolved by the geophysical data) and/or abundant, occurring below all parts of the pluton. If the proposed small-scale sheets with radii of $<2-5 \mathrm{~km}$ exist (model 2), vertical magma feeder zones must be abundant.

\section{Conclusions}

We have used a combination of multidisciplinary methods, including field and microscopic observations, AMS fabric characterization, and Bouguer gravity modeling, to decipher the emplacement processes for the Jurassic Qitianling granitic pluton, South China. The results indicate that the Qitianling pluton forms an $\sim 25-\mathrm{km}$-wide and $\sim 6-\mathrm{km}$-thick lopolith-like intrusion that was incrementally emplaced by multiple magma sheets during a period of tectonic quiescence, that is, that emplacement was largely driven by internal magma forces, while preexisting (pre-Jurassic), passive crustal-scale faults are inferred to have facilitated magma ascent and heat transfer from the cooling pluton. We consider that the pluton either formed by accumulation of large magma sheets ( $>20 \mathrm{~km}$ in diameter) that fractionated in situ or that it formed by emplacement of multiple small magma sheets that represent magma fractionated at deeper crustal level or compositionally variable source-derived melts.

To unequivocally distinguish between these modes of pluton construction, additional high-precision dating is urgently needed. We highlight that AMS fabric characterization can be particularly useful in mapping out suspected magma sheets with cryptic contacts and weak internal fabrics in granite plutons and for identifying crucial targets for high-precision age dating. The outcrop spacing and the overall exposure of the Qitianling pluton were insufficient to map out individual magma sheets where they may be present (e.g., following zones with moderately steep foliations), but high-precision age dating will target these zones (outcrops on both sides of steep to moderately steep foliations) to unequivocally constrain and further characterize age variation of the exposed facies I to III granites.

We highlight that the Jurassic was a period of relative "tectonic quiescence" in the SCB, where regional deformation mostly formed large, open-scale fold belts. If and how the volumetrically significant granite magmatism has affected, and perhaps even controlled, regional deformation (e.g., de Saint Blanquat et al., 2011; Merle \& Vendeville, 1995) is a target of current field investigations and numerical modeling.

\section{References}

Allibon, J., Bussy, F., Lewin, E., \& Darbellay, B. (2011). The tectonically controlled emplacement of a vertically sheeted gabbro-pyroxenite intrusion: feeder-zone of an ocean-island volcano (Fuerteventura, Canary Islands). Tectonophysics, 500(1), 78-97.

Annen, C., Blundy, J., \& Sparks, R. (2006). The genesis of intermediate and silicic magmas in deep crustal hot zones. Journal of Petrology, 47(3), 505-539.

Annen, C., Blundy, J. D., Leuthold, J., \& Sparks, R. S. J. (2015). Construction and evolution of igneous bodies: Towards an integrated perspective of crustal magmatism. Lithos, 230, 206-221.

Bai, D. Y., Chen, J. C., Ma, T. Q., \& Wang, X. H. (2005). Geochemical characteristics and tectonic setting of Qitianling A_Type granitic pluton in southeast Hunan [in Chinese with English abstract]. Acta Petrologica et Mineralogica, 24(4), 255-272.

Bain, A. A., Jellinek, A., \& Wiebe, R. (2013). Quantitative field constraints on the dynamics of silicic magma chamber rejuvenation and overturn. Contributions to Mineralogy and Petrology, 165(6), 1275-1294. 
Bateman, R. (1984). On the role of diapirism in the, segregation, ascent and final emplacement of granitoid magmas. Tectonophysics, 110(3-4), 211-231.

BGMRHN (Bureau of Geology and Mineral Resources of Hunan Province) (1988). Regional geology of Hunan Province [in Chinese with English Abstract (pp. 6-664). Beijing: Geological Publishing House.

Blundy, J. D., \& Annen, C. J. (2016). Crustal magmatic systems from the perspective of heat transfer. Elements, 12(2), 115-120.

Borradaile, G. J., \& Henry, B. (1997). Tectonic applications of magnetic susceptibility and its anisotropy. Earth-Science Reviews, 42(1), 49-93. https://doi.org/10.1016/S0012-8252(96)00044-X

Borradaile, G. J., \& Mothersill, J. S. (1984). Coaxial deformed and magnetic fabrics without simply correlated magnitudes of principal values. Physics of the Earth and Planetary Interiors, 35(4), 294-300. https://doi.org/10.1016/0031-9201(84)90023-2

Bouilhol, P., Schmidt, M., \& Burg, J.-P. (2015). Magma transfer and evolution in channels within the arc crust: The pyroxenitic feeder pipes of Sapat (Kohistan, Pakistan). Journal of Petrology, 56(7), 1309-1342.

Byerly, A., Tikoff, B., Kahn, M., Jicha, B., Gaschnig, R., \& Fayon, A. K. (2016). Internal fabrics of the Idaho batholith, USA. Lithosphere. https://doi. org/10.1130/1551.1

Caricchi, L., Annen, C., Blundy, J., Simpson, G., \& Pinel, V. (2014). Frequency and magnitude of volcanic eruptions controlled by magma injection and buoyancy. Nature Geoscience, 7(2), 126.

Charvet, J., Shu, L., Faure, M., Choulet, F., Wang, B., Lu, H., \& Le Breton, N. (2010). Structural development of the Lower Paleozoic belt of South China: Genesis of an intracontinental orogen. Journal of Asian Earth Sciences, 39(4), 309-330.

Chen, J., \& Jahn, B.-m. (1998). Crustal evolution of southeastern China: Nd and Sr isotopic evidence. Tectonophysics, 284(1), 101-133. https:// doi.org/10.1016/S0040-1951(97)00186-8

Chu, Y., Lin, W., Faure, M., Wang, Q., \& Ji, W. (2012). Phanerozoic tectonothermal events of the Xuefengshan Belt, central South China: Implications from UPb age and LuHf determinations of granites. Lithos, 150, 243-255. https://doi.org/10.1016/j.lithos.2012.04.005

Clemens, J., Buick, I., \& Kisters, A. (2017). The Donkerhuk batholith, Namibia: A giant S-type granite emplaced in the mid crust, in a fore-arc setting. Journal of the Geological Society, 174(1), 157-169.

Coleman, D. S., Gray, W., \& Glazner, A. F. (2004). Rethinking the emplacement and evolution of zoned plutons: Geochronologic evidence for incremental assembly of the Tuolumne Intrusive Suite, California. Geology, 32(5), 433. https://doi.org/10.1130/g20220.1

Cruden, A. R. (1998). On the emplacement of tabular granites. Journal of the Geological Society of London, 155(5), 853-862.

Day, R., Fuller, M., \& Schmidt, V. A. (1977). Hysteresis properties of titanomagnetites: Grain-size and compositional dependence. Physics of the Earth and Planetary Interiors, 13(4), 260-267. https://doi.org/10.1016/0031-9201(77)90108-X

Deng, X. G., Li, X. H., Liu, Y. M., Huang, G. F., \& Hou, M. S. (2005). Geochemical characteristics of Qitianling granites and their implications for mineralization. Acta Petrologica et Mineralogica, 24(2), 93-102. https://doi.org/10.3969/j.issn.1000-6524.2005.02.002

Deng, Y., Zhang, Z., Badal, J., \& Fan, W. (2014). 3-D density structure under South China constrained by seismic velocity and gravity data. Tectonophysics, 627, 159-170. https://doi.org/10.1016/j.tecto.2013.07.032

Deniel, C., Vidal, P., Fernandez, A., Le Fort, P., \& Peucat, J. J. (1987). Isotopic study of the Manaslu granite (Himalaya, Nepal): Inferences on the age and source of Himalayan leucogranites. Contributions to Mineralogy and Petrology, 96(1), 78-92.

de Saint Blanquat, M., Horsman, E., Habert, G., Morgan, S., Vanderhaeghe, O., Law, R., \& Tikoff, B. (2011). Multiscale magmatic cyclicity, duration of pluton construction, and the paradoxical relationship between tectonism and plutonism in continental arcs. Tectonophysics, 500(1), 20-33. https://doi.org/10.1016/j.tecto.2009.12.009

de Saint Blanquat, M., \& Tikoff, B. (1997). Development of magmatic to solid-state fabrics during syntectonic emplacement of the Mono Creek Granite, Sierra Nevada Batholith. In J. L. Bouchez, D. H. W. Hutton, \& W. E. Stephens (Eds.), Granite: From Segregation of Melt to Emplacement Fabrics (pp. 231-252). Dordrecht, Netherlands: Springer.

de Saint-Blanquat, M., Habert, G., Horsman, E., Morgan, S. S., Tikoff, B., Launeau, P., \& Gleizes, G. (2006). Mechanisms and duration of non-tectonically assisted magma emplacement in the upper crust: The Black Mesa pluton, Henry Mountains, Utah. Tectonophysics, 428(1-4), 1-31. https://doi.org/10.1016/j.tecto.2006.07.014

de Saint-Blanquat, M., Law, R. D., Bouchez, J.-L., \& Morgan, S. S. (2001). Internal structure and emplacement of the Papoose Flat pluton: An integrated structural, petrographic, and magnetic susceptibility study. Geological Society of America Bulletin, 113(8), 976-995. https://doi. org/10.1130/0016-7606(2001)113<0976:isaeot $>2.0 . c 0 ; 2$

Dumond, G., Yoshinobu, A. S., \& Barnes, C. G. (2005). Midcrustal emplacement of the Sausfjellet pluton, central Norway: Ductile flow, stoping and in situ assimilation. Geological Society of America Bulletin, 117(3-4), 383-395.

Dunlop, D. J. (2002). Theory and application of the day plot (Mrs/Ms versus Hcr/Hc) 2. Application to data for rocks, sediments, and soils. Journal of Geophysical Research, 107(B3), 2057. https://doi.org/10.1029/2001JB000487

Faure, M., Lepvrier, C., Nguyen, V. V., Vu, T. V., Lin, W., \& Chen, Z. (2014). The South China Block-Indochina collision: Where, when, and how? Journal of Asian Earth Sciences, 79, 260-274. https://doi.org/10.1016/j.jseaes.2013.09.022

Faure, M., Lin, W., Chu, Y., \& Lepvrier, C. (2016). Triassic tectonics of the southern margin of the South China Block. Comptes Rendus Geoscience, 348(1), 5-14.

Faure, M., Lin, W., Monié, P., \& Meffre, S. (2008). Palaeozoic collision between the North and South China Blocks, Triassic intracontinental tectonics, and the problem of the ultrahigh-pressure metamorphism. Comptes Rendus Geoscience, 340(2), 139-150.

Faure, M., Shu, L., Wang, B., Charvet, J., Choulet, F., \& Monié, P. (2009). Intracontinental subduction: A possible mechanism for the Early Palaeozoic Orogen of SE China. Terra Nova, 21(5), 360-368.

Feng, Z., Wang, C., Zhang, M., \& Liang, J. (2012). Unusually dumbbell-shaped Guposhan-Huashan twin granite plutons in Nanling Range of south China: Discussion on their incremental emplacement and growth mechanism. Journal of Asian Earth Sciences, 48 $9-23$

Fletcher, C. J., Chan, L. S., Sewell, R. J., Campbell, S. D. G., Davis, D. W., \& Zhu, J. (2004). Basement heterogeneity in the Cathaysia crustal block, southeast China. Geological Society, London, Special Publications, 226(1), 145-155.

Fu, J.-m., Ma, C.-q., Xie, C.-f., Zhang, Y.-m., \& Song-bai, P. (2004). Zircon SHRIMP dating of the Cailing granite on the eastern margin of the Qitianling granite, Hunan, South China, and its significance [J] [in Chinese with English abstract]. Geology in China, 31(1), 96-100.

Gao, S., Yang, J., Zhou, L., Li, M., Hu, Z., Guo, J., et al. (2011). Age and growth of the Archean Kongling terrain, South China, with emphasis on 3.3 ga granitoid gneisses. American Journal of Science, 311(2), 153-182. https://doi.org/10.2475/02.2011.03

Gilder, S. A., Leloup, P. H., Courtillot, V., Chen, Y., Coe, R. S., Zhao, X., et al. (1999). Tectonic evolution of the Tancheng-Lujiang (Tan-Lu) fault via Middle Triassic to Early Cenozoic paleomagnetic data. Journal of Geophysical Research, 104(B7), 15365-15390. https://doi.org/10.1029/ $1999 j b 900123$

Gudmundsson, A. (2011). Deflection of dykes into sills at discontinuities and magma-chamber formation. Tectonophysics, 500(1), 50-64. https://doi.org/10.1016/j.tecto.2009.10.015 
Guo, Y. Z. (2006). A study on magnetic field gradient vector structure used to locate stannic enrichment ore body in Qitianling multi-metal ore area, South Hunan Province [in Chinese with English abstract]. Acta Geologica Sinica, 80(10), 1553-1557.

Hammarstrom, J. M., \& Zen, E. (1986). Aluminum in hornblende: An empirical igneous geobarometer. American Mineralogist, 71(11-12), 1297-1313.

He, B., Xu, Y.-G., \& Paterson, S. (2009). Magmatic diapirism of the Fangshan pluton, southwest of Beijing, China. Journal of Structural Geology, $31(6), 615-626$.

Hollister, L. S., Grissom, G. C., Peters, E. K., Stowell, H. H., \& Sisson, V. B. (1987). Confirmation of the empirical correlation of Al in hornblende with pressure of solidification of calc-alkaline plutons. American Mineralogist, 72(3-4), 231-239.

Horsman, E., Morgan, S., de Saint-Blanquat, M., Habert, G., Nugent, A., Hunter, R. A., \& Tikoff, B. (2009). Emplacement and assembly of shallow intrusions from multiple magma pulses, Henry Mountains, Utah. Earth and Environmental Science Transactions of the Royal Society of Edinburgh, 100(1-2), 117-132.

Horsman, E., Tikoff, B., \& Morgan, S. (2005). Emplacement-related fabric and multiple sheets in the Maiden Creek sill, Henry Mountains, Utah, USA. Journal of Structural Geology, 27(8), 1426-1444. https://doi.org/10.1016/j.jsg.2005.03.003

Huang, J. (1945), On major tectonic forms of China, National Geological Survey of China under the Ministry of Economic Affairs.

Hutton, D. H. (1992). Granite sheeted complexes: Evidence for the dyking ascent mechanism. Geological Society of America Special Papers, $272,377-382$.

John, B. E., \& Blundy, J. D. (1993). Emplacement-related deformation of granitoid magmas, southern Adamello Massif, Italy. Geological Society of America Bulletin, 105(12), 1517-1541.

Kratinová, Z., Závada, P., Hrouda, F., \& Schulmann, K. (2006). Non-scaled analogue modelling of AMS development during viscous flow: A simulation on diapir-like structures. Tectonophysics, 418(1), 51-61.

Kruhl, J. H., Erdmann, S., \& Büttner, S. H. (2007). Brittle-ductile microfabrics in naturally deformed cordierite: Evidence for significant shortterm strain-rate variations. Journal of Structural Geology, 29(2), 355-374.

Li, H., Lu, Y., Wang, D., Chen, Y., Yang, H., Guo, J., et al. (2006). Dating of the rock-forming and ore-forming ages and their geological significances in the Furong Ore-field, QitianMoutain, Hunan [in Chinese with English abstract]. Geological Review, 52(1), $113-121$.

Li, J. D., Bai, D. Y., Wu, G. Y., Che, Q. J., Liu, Y. R., \& Ma, T. Q. (2005). Zircon SHRIMP dating of the Qitianling granite, Chenzhou, southern Hunan, and its geological significance [in Chinese with English abstract]. Geological Bulletin of China, 24(5), 411-414.

Li, X.-H., Li, W.-X., Li, Z.-X., \& Liu, Y. (2008). 850-790 Ma bimodal volcanic and intrusive rocks in northern Zhejiang, South China: A major episode of continental rift magmatism during the breakup of Rodinia. Lithos, 102(1-2), 341-357. https://doi.org/10.1016/j. lithos.2007.04.007

Lin, W., Faure, M., Wang, Q., Monié, P., \& Panis, D. (2005). Triassic polyphase deformation in the Feidong-Zhangbaling Massif (eastern China) and its place in the collision between the North China and South China Blocks. Journal of Asian Earth Sciences, 25(1), 121-136.

Martelet, G., Perrin, J., Truffert, C., \& Deparis, J. (2013). Fast mapping of magnetic basement depth, structure and nature using aeromagnetic and gravity data: Combined methods and their application in the Paris Basin. Geophysical Prospecting, 61(4), 857-873. https://doi.org/ $10.1111 / 1365-2478.12024$

Mathieu, L., De Vries, B. V. W., Holohan, E. P., \& Troll, V. R. (2008). Dykes, cups, saucers and sills: Analogue experiments on magma intrusion into brittle rocks. Earth and Planetary Science Letters, 271(1), 1-13.

Matzel, J. E., Bowring, S. A., \& Miller, R. B. (2006). Time scales of pluton construction at differing crustal levels: Examples from the Mount Stuart and Tenpeak intrusions, North Cascades, Washington. Geological Society of America Bulletin, 118(11-12), 1412-1430.

McNulty, B. A., Tobisch, O. T., Cruden, A. R., \& Gilder, S. (2000). Multistage emplacement of the Mount Givens pluton, central Sierra Nevada batholith, California. Geological Society of America Bulletin, 112(1), 119-135.

Merle, O., \& Vendeville, B. (1995). Experimental modelling of thin-skinned shortening around magmatic intrusions. Bulletin of Volcanology, $57(1), 33-43$.

Morgan, S., Jones, R., Conner, J., Student, J., Schaner, M., Horsman, E., \& Michel, D. S. B. (2017). Magma sheets defined with magnetic susceptibility in the Maiden Creek sill, Henry Mountains, Utah, USA. Geology, 45(7), 599-602.

Morgan, S. S., Law, R. D., \& Nyman, M. W. (1998). Laccolith-like emplacement model for the Papoose Flat pluton based on porphyroblastmatrix analysis. Geological Society of America Bulletin, 110(1), 96-110.

Ni, N., Chen, N., Chen, J., \& Liu, M. (2016). Integrating WorldView-2 imagery and terrestrial LiDAR point clouds to extract dyke swarm geometry: Implications for magma emplacement mechanisms. Journal of Volcanology and Geothermal Research, 310, 1-11.

O'Driscoll, B., Troll, V. R., Reavy, R. J., \& Turner, P. (2006). The Great Eucrite intrusion of Ardnamurchan, Scotland: Reevaluating the ring-dike concept. Geology, 34(3), 189-192. https://doi.org/10.1130/g22294.1

Passchier, C. W., \& Trouw, R. A. J. (1998). Deformation Mechanisms. In C. W. Passchier \& R. A. J. Trouw (Eds.), Microtectonics (pp. 25-56). Berlin, Heidelberg: Springer.

Paterson, S. R. (2009). Magmatic tubes, pipes, troughs, diapirs, and plumes: Late-stage convective instabilities resulting in compositional diversity and permeable networks in crystal-rich magmas of the Tuolumne batholith, Sierra Nevada, California. Geosphere, 5(6), $496-527$. https://doi.org/10.1130/ges00214.1

Petford, N., Cruden, A. R., McCaffrey, K. J. W., \& Vigneresse, J. L. (2000). Granite magma formation, transport and emplacement in the Earth's crust. Nature, 408(6813), 669-673.

Potro, R., Díez, M., Blundy, J., Camacho, A. G., \& Gottsmann, J. (2013). Diapiric ascent of silicic magma beneath the Bolivian Altiplano. Geophysical Research Letters, 40, 2044-2048. https://doi.org/10.1002/grl.50493

Scaillet, B., Holtz, F., Pichavant, M., \& Schmidt, M. (1996). Viscosity of Himalayan leucogranites: Implications for mechanisms of granitic magma ascent. Journal of Geophysical Research, 101(B12), 27,691-27,699. https://doi.org/10.1029/96JB01631

Scaillet, B., Pêcher, A., Rochette, P., \& Champenois, M. (1995). The Gangotri granite (Garhwal Himalaya): Laccolithic emplacement in an extending collisional belt. Journal of Geophysical Research, 100(B1), 585-607. https://doi.org/10.1029/94JB01664

Scaillet, B., \& Searle, M. P. (2006). Mechanisms and timescales of felsic magma segregation, ascent and emplacement in the Himalaya. Geological Society, London, Special Publications, 268(1), 293-308.

Schoene, B., Samperton, K. M., Eddy, M. P., Keller, G., Adatte, T., Bowring, S. A., et al. (2015). U-Pb geochronology of the Deccan Traps and relation to the end-Cretaceous mass extinction. Science, 347(6218), 182.

Schofield, N. J., Brown, D. J., Magee, C., \& Stevenson, C. T. (2012). Sill morphology and comparison of brittle and non-brittle emplacement mechanisms. Journal of the Geological Society, 169(2), 127-141.

Shu, L., Zhou, X., Deng, P., Wang, B., Jiang, S.-Y., Yu, J., \& Zhao, X. (2009). Mesozoic tectonic evolution of the Southeast China Block: New insights from basin analysis. Journal of Asian Earth Sciences, 34(3), 376-391. 
Shu, L. S. (2012). An analysis of principal features of tectonic evolution in South China Block [in Chinese with English abstract]. Geological Bulletin of China, 31(7), 1035-1053.

Shu, L.-S., Faure, M., Yu, J.-H., \& Jahn, B.-M. (2011). Geochronological and geochemical features of the Cathaysia block (South China): New evidence for the Neoproterozoic breakup of Rodinia. Precambrian Research, 187(3-4), 263-276. https://doi.org/10.1016/j. precamres.2011.03.003

Shu, X.-J., Wang, X.-L., Sun, T., Xu, X., \& Dai, M.-N. (2011). Trace elements, U-Pb ages and Hf isotopes of zircons from Mesozoic granites in the western Nanling Range, South China: Implications for petrogenesis and W-Sn mineralization. Lithos, 127(3-4), 468-482. https://doi.org/ 10.1016/j.lithos.2011.09.019

Stevenson, C. T. E., Owens, W. H., Hutton, D. H. W., Hood, D. N., \& Meighan, I. G. (2007). Laccolithic, as opposed to cauldron subsidence, emplacement of the Eastern Mourne pluton, N. Ireland: Evidence from anisotropy of magnetic susceptibility. Journal of the Geological Society, 164(1), 99-110. https://doi.org/10.1144/0016076492006-008

Tarling, D., and F. Hrouda (1993), Magnetic anisotropy of rocks, Springer Science \& Business Media.

van der Pluijm, B. A., \& Marshak, S. (2004). Earth structure: An Introduction to Structural Geology and Tectonics. New York: W. W. Norton \& Company, Inc.

Vigneresse, J. L. (1990). Use and misuse of geophysical data to determine the shape at depth of granitic intrusions. Geological Journal, 25 , 249-260. https://doi.org/10.1002/gj.3350250308

Wan, Y., Liu, D., Xu, M., Zhuang, J., Song, B., Shi, Y., \& Du, L. (2007). SHRIMP U-Pb zircon geochronology and geochemistry of metavolcanic and metasedimentary rocks in Northwestern Fujian, Cathaysia block, China: Tectonic implications and the need to redefine lithostratigraphic units. Gondwana Research, 12(1-2), 166-183. https://doi.org/10.1016/j.gr.2006.10.016

Wang, J., \& Li, Z.-X. (2003). History of Neoproterozoic rift basins in South China: Implications for Rodinia break-up. Precambrian Research $122(1), 141-158$.

Wang, Y., Fan, W., Sun, M., Liang, X., Zhang, Y., \& Peng, T. (2007). Geochronological, geochemical and geothermal constraints on petrogenesis of the Indosinian peraluminous granites in the South China Block: A case study in the Hunan Province. Lithos, 96(3-4), 475-502. https:// doi.org/10.1016/j.lithos.2006.11.010

Wang, Y., Fan, W., Zhang, G., \& Zhang, Y. (2013). Phanerozoic tectonics of the South China Block: Key observations and controversies. Gondwana Research, 23(4), 1273-1305. https://doi.org/10.1016/j.gr.2012.02.019

Wang, Y., Zhang, F., Fan, W., Zhang, G., Chen, S., Cawood, P. A., \& Zhang, A. (2010). Tectonic setting of the South China Block in the early Paleozoic: Resolving intracontinental and ocean closure models from detrital zircon U-Pb geochronology. Tectonics, 29, TC6020. https:// doi.org/10.1029/2010TC002750

Wei, W., Chen, Y., Faure, M., Martelet, G., Lin, W., Wang, Q., et al. (2016). An early extensional event of the South China Block during the Late Mesozoic recorded by the emplacement of the Late Jurassic syntectonic Hengshan Composite Granitic Massif (Hunan, SE China). Tectonophysics, 672-673, 50-67. https://doi.org/10.1016/j.tecto.2016.01.028

Xie, L., Wang, R.-C., Chen, J., \& Zhu, J.-C. (2010). Mineralogical evidence for magmatic and hydrothermal processes in the Qitianling oxidized tin-bearing granite (Hunan, South China): EMP and (MC)-LA-ICPMS investigations of three types of titanite. Chemical Geology, 276(1-2), 53-68. https://doi.org/10.1016/j.chemgeo.2010.05.020

Yan, D.-P., Zhou, M.-F., Li, S.-B., \& Wei, G.-Q. (2011). Structural and geochronological constraints on the Mesozoic-Cenozoic tectonic evolution of the Longmen Shan thrust belt, eastern Tibetan Plateau. Tectonics, 30, TC6005. https://doi.org/10.1029/2011TC002867

Yu, J.-H., O'Reilly, S. Y., Wang, L., Griffin, W. L., Zhou, M.-F., Zhang, M., \& Shu, L. (2010). Components and episodic growth of Precambrian crust in the Cathaysia Block, South China: evidence from U-Pb ages and Hf isotopes of zircons in Neoproterozoic sediments. Precambrian Research, 181(1), 97-114.

Yu, J.-H., Wang, L., O'Reilly, S. Y., Griffin, W. L., Zhang, M., Li, C., \& Shu, L. (2009). A Paleoproterozoic orogeny recorded in a long-lived cratonic remnant (Wuyishan terrane), eastern Cathaysia Block, China. Precambrian Research, 174(3-4), 347-363. https://doi.org/10.1016/j. precamres.2009.08.009

Zhang, G., Guo, A., Wang, Y., Li, S., Dong, Y., Liu, S., et al. (2013). Tectonics of South China continent and its implications. Science China Earth Sciences, 56(11), 1804-1828.

Zhao, K.-D., Jiang, S.-Y., Jiang, Y.-H., \& Wang, R.-C. (2005). Mineral chemistry of the Qitianling granitoid and the Furong tin oredeposit in Hunan Province, South China. European Journal of Mineralogy, 17(4), 635.

Zheng, Y.-F., Wu, R.-X., Wu, Y.-B., Zhang, S.-B., Yuan, H., \& Wu, F.-Y. (2008). Rift melting of juvenile arc-derived crust: Geochemical evidence from Neoproterozoic volcanic and granitic rocks in the Jiangnan Orogen, South China. Precambrian Research, 163(3-4), 351-383. https:// doi.org/10.1016/j.precamres.2008.01.004

Zhou, X., Sun, T., Weizhou, S., Shu, L., \& Yaoling, N. (2006). Petrogenesis of Mesozoic granitoids and volcanic rocks in South China: A response to tectonic evolution. Episodes, 29(1), 26-33.

Zhu, J., Huang, G., Zhang, P., Li, F., \& Rao, B. (2003). On the emplacement age and material sources for the granites of Cailingsuperunit, Qitianling pluton, south Hunan Province [in Chinese with English abstract]. Geological Review, 49(3), $245-252$.

Zhu, J., Wang, R.-C., Zhang, P.-H., Xie, C.-F., Zhang, W.-L., Zhao, K.-D., et al. (2009). Zircon U-Pb geochronological framework of Qitianling granite batholith, middle part of Nanling Range, South China. Science in China Series D: Earth Sciences, 52(9), 1279-1294. https://doi.org/ 10.1007/s11430-009-0154-4

Zhu, J., Zhang, H., Xie, C. F., Zhang, P. H., \& Yang, C. (2005). Zircon SHRIMP U-Pb geochronology, petrology and geochemistry of the Zhujianshui granite, Qitianling pluton, Southern Hunan Province [in Chinese with English abstract]. Geological Journal of China Universities, 11(3), 335-342. 